\title{
Lake Bonneville:
}

Geology of

Southern Utah Valley

Utah

GEOLOGICAL SURVEY PROFESSIONAL PAPER 257-B

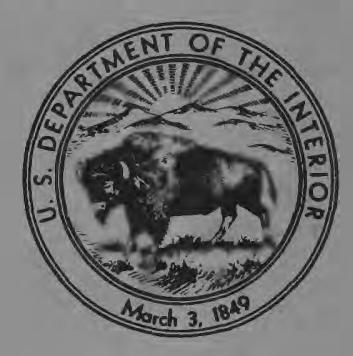




\section{Lake Bonneville:}

Geology of

Southern Utah Valley

Utah

By HAROLD J. BISSELL

GEOLOGICAL SURVEY PROFESSIONAL PAPER 257-B

Stratigraphy, origin, and engineering properties of the unconsolidated deposits of Pleistocene Lake Bonneville

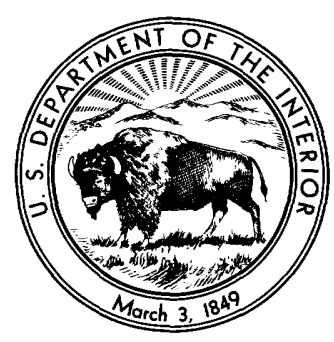

UNITED STATES GOVERNMENT PRINTING OFFICE, WASHINGTON : 1963 


\section{UNITED STATES DEPARTMENT OF THE INTERIOR \\ STEWART L. UDALL, Secretary \\ GEOLOGICAL SURVEY \\ Thomas B. Nolan, Director}

For sale by the Superintendent of Documents, U.S. Government Printing Office Washington 25, D.C. 


\section{CONTENTS}

Abstract

Introduction $\ldots$

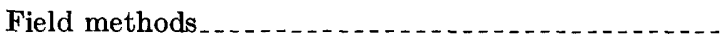

Previous studies . .

Acknowledgments..............

Physical geography ...

Chemical quality of water in Utah Lake.........

Climate

Culture and accessibility .........

Stratigraphy _.........

Pre-Quaternary rocks.

Quaternary deposits in the mountains adjoining

southern Utah Valley . . . . . . . . . . . . . . . . .

Quaternary deposits in southern Utah Valley.......

Pre-Lake Bonneville fan gravel ..............

Lake Bonneville group. . . . . . . . . . . . . .

Alpine formation . . . .

Bonneville formation.

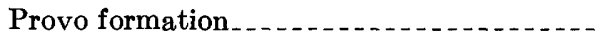

Fan gravel of Lake Bonneville age
Page

101

101

101

102

103

103

104

105

105

106

106

107

107

107

107

108

111

113

121

Stratigraphy-Continued

Quaternary deposits in southern Utah Valley-Con.

Younger deposits ..............................

Post-Provo eolian sand and silt..........

Late and post-Provo, pre-Utah Lake fan

gravel _....... 121

Deposits of Utah Lake.............. 122

Alluvium of Utah Lake age ........... 123

Comparison of fauna of Utah Lake and

Lake Bonneville ages................. 123

Ancient soils _........

Lake history _. . . .

Structural geology

Engineering geology

Gravel

Sand

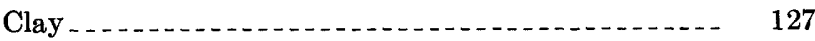

Other materials

References cited...

Index

\section{ILLUSTRATIONS}

Plate 5. Geologic map of southern Utah Valley

Figure 23. Index map of Lake Bonneville

24. Aerial view of Wasatch Mountains south of Salem showing pre-Lake Bonneville alluvial fan . . . . . . . .

25. Bedding in silt member of the Alpine formation.

26. Varvelike silt and clay in the Alpine formation

27. Disconformity between the Bonneville and Alpine formation

28. Bar graphs of mechanical analyses of gravel from the Bonneville formation

29. Disconformity between the Alpine and Bonneville formations

30. Diagrammatic sketch of disconformity between the Alpine and Bonneville formations

31. Sorting in gravel of the Provo formation

32. Post-Provo, pre-Utah Lake soil, developed on deltaic gravel of the Provo formation

33. Delta deposit of the Provo formation

34. Bar graphs of mechanical analyses of the gravel member of the Provo formation

35. Deltaic silt and fine sand in the silt member of the Provo formation

36. Gravel member of the Provo formation overlain by the diatomaceous unit of the silt member

37. Tufa in Utah Lake deposits

\section{TABLES}

TABLE 1. Chemical analyses of water in Utah Lake, 1883 to 1933

2. Chemical analyses of water in Utah Lake, 1933

3. Chemical analyses of water from thermal springs in or near Utah Lake

4. Chemical analyses of water of surface streams emptying into Utah Lake

5. Annual precipitation at various weather stations in southern Utah Valley

6. Monthly and annual mean temperatures in southern Utah Valley

7. Highest temperature, lowest temperature, and prevailing wind direction in southern Utah Valley

8. Mechanical analyses of six samples of the gravel member of the Alpine formation

9. Mechanical analyses of eight samples of the silt member of the Alpine formation

10. Mechanical analyses of the gravel member of the Provo formation

11. Mechanical analyses of the sand member of the Provo formation

12. Mechanical analyses of the silt member of the Provo formation 



\title{
LAKE BONNEVILLE: GEOLOGY OF SOUTHERN UTAH VALLEY, UTAH
}

\author{
By Harold J. Bisselel
}

\begin{abstract}
Southern Utah Valley is an area of about 400 square miles at the east edge of Pleistocene Lake Bonneville.

The valley floor consists mostly of sediments of Lake Bonneville and younger lakes. The sediments of Lake Bonneville overlap upon huge alluvial fans of pre-Lake Bonneville age and spread into the valley from the adjoining mountains. The fan gravel bears a very mature (strongly developed) ancient soil, commonly 10 feet or more thick, which also is of pre-Lake Bonneville age.

The sediments of Lake Bonneville, the Lake Bonneville group, consist of three formations: the Alpine (oldest), Bonneville, and the Provo (youngest).

The Alpine formation, as much as 335 feet in exposed thickness, is divided into gravel, sand, silt, and clay members, depending on the dominant texture. Silt and clay predominate. This formation records the first deep-water cycle of Lake Bonneville and extends to an altitude of about 5,100 feet, the maximum of this lake cycle.

A disconformity, representing subaerial erosion, a submature soil, and loess and alluvium locally separate the Alpine and Bonneville formations. These subaerial features occur at altitudes as low as about 4,840 feet in southern Utah Valley and indicate lake recession was at least this low between the Alpine and Bonneville lake cycles.
\end{abstract}

The Bonneville formation is much thinner, generally less than 35 feet thick, and is the smallest in volume of the Lake Bonneville group. It occurs mainly as a discontinuous selvage of gravel along the highest shoreline of Lake Bonneville, the Bonneville shoreline of Gilbert, at an altitude of about 5,135 feet; it also occurs locally as small spits and bars at lower altitudes. It records the second deep-lake cycle of Lake Bonneville. A maturely developed soil, generally 3 to 4 feet thick, occurs on the Alpine and Bonneville formations above the Provo shoreline, and presumably is of post-Bonneville formation, Provo or preProvo age.

The Provo formation, youngest of the Lake Bonneville group and about 100 feet in maximum thickness, was deposited after the lake had receded to the Provo shoreline, 335 feet below the Bonneville shoreline, at an altitude of about 4,800 feet. This formation also is divided into gravel, sand, silt, and clay members. In the eastern part of the valley huge deltas of Provo age, mostly gravel, were built at the mouths of the streams draining from the Wasatch Mountains. A disconformity representing subaerial erosion, eolian sand and silt, and a submature soil locally separate the lake deposits of the uppermost part of this formation from the main part. These subaerial features have been found at altitudes as low as 4,720 feet indicating intra-Provo lake recession at least this low; the overlying lake sediments reach 4,760 feet indicating a minor late Provo lake readvance to this altitude.
A submature soil, as much as 2 feet thick, has formed on the uppermost beds of the Provo formation, but not on younger deposits.

Fan gravel of late- and post-Provo age overlies the Provo formation; the gravel was deposited as streams incised the deltas during the final recession of Lake Bonneville, in late Provo time. Other post-Provo deposits include those of Utah Lake, which are 50 feet in maximum thickness and are subdivided into gravel, sand, silt, clay, and tufa units; eolian sand; and alluvium of Utah Lake age, deposited on the youngest fans and modern stream flood plains.

The lacustrine mollusks of different ages show slight differences. A few species found in the deposits of Utah Lake have not been found in the Lake Bonneville group, and a few species found in the Provo formation have not been found in the Alpine. Also, the coiling of the gastropods seems to be wholly dextral in the Alpine formation and partly sinistral in the Provo.

Utah Valley is a structural valley bounded by faults, but folding has contributed to the deformation. Deformation has occurred repeatedly - at least twice in the Precambrian and again midway in Cretaceous, Late Cretaceous, Early Tertiary, Late Tertiary, and in Quaternary time-and is still continuing. The pre-Lake Bonneville fan gravel is faulted as much as 150 feet, and the Lake Bonneville group is displaced as much as $\mathbf{5 0}$ feet by later fault movements.

The gravel, sand, and clay in the valley are used extensively as construction materials.

\section{INTRODUCTION}

Utah Valley, in the northern part of central Utah, is an intermontane basin at the eastern margin of the Basin and Range province (Fenneman, 1928). Bounded on the east by the Wasatch Mountains and on the west by the East Tintic and the Lake Mountains, it extends north from a low pass at the north end of Juab Valley to the Traverse Range, which separates Utah Valley from Salt Lake Valley (fig. 23). This report considers the south half of this valley, an area of about 400 square miles. The geology of the north half, north of an east-west line through the south edge of Provo, has been mapped by Hunt, Varnes, and Thomas (1953).

\section{FIELD METHODS}

The fieldwork on which this report is based was begun in 1937 and continued intermittently during parts of $1938,1939,1940,1942$, and 1943. Most of the mapping, however, was done between January 1947 and 


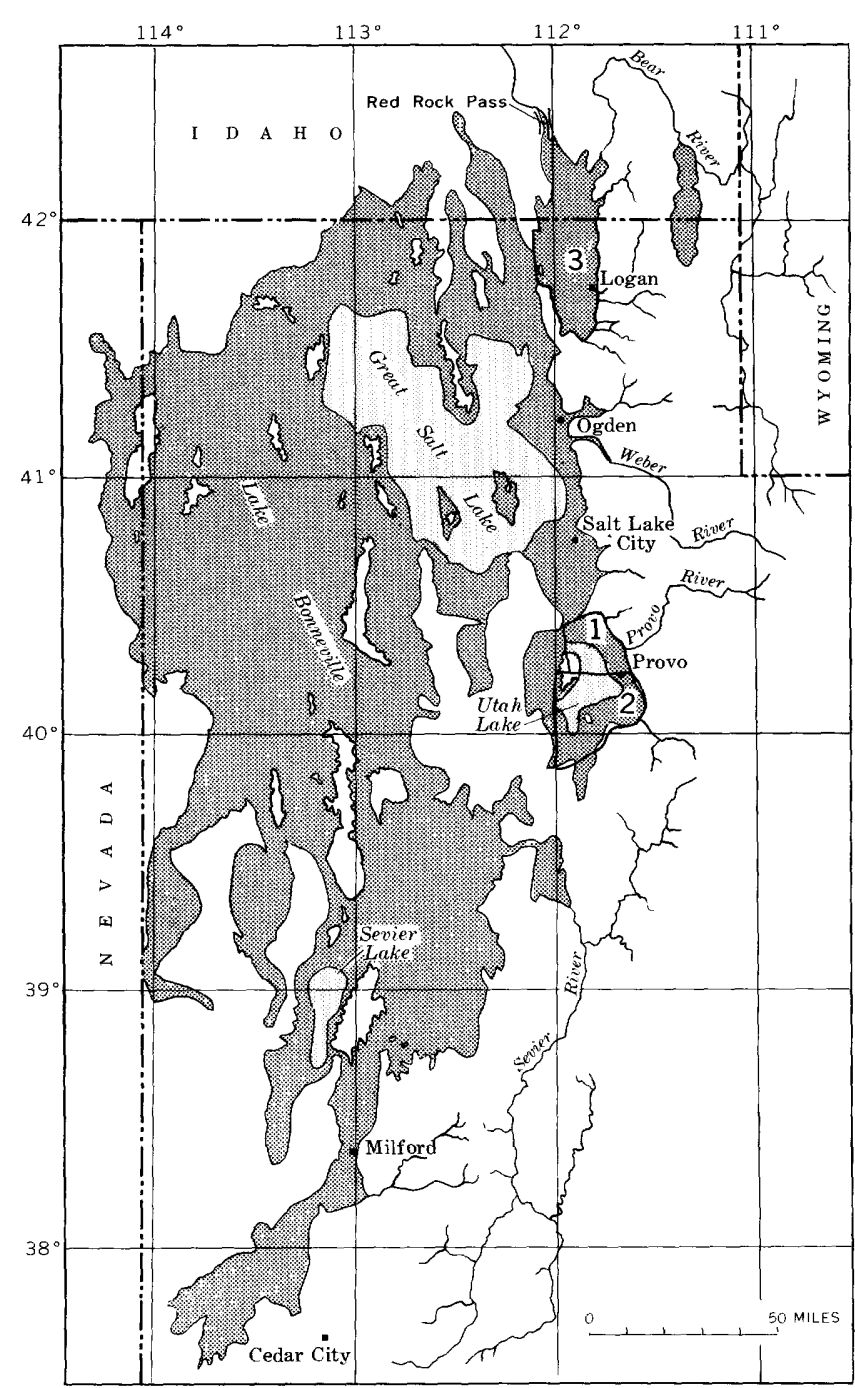

FIGURE 23-Index map of Lake Bonneville showing the areas covered in Professional Paper 257. 1, Northern Utah Valley (chap. A). 2, Southern Utah Valley (chap. B). 3, Cache Valley (chap. C).

July 1951 as part of the U.S. Geological Survey mapping program in the Lake Bonneville basin.

At the beginning of fieldwork few maps useful as a working base existed, but as work progressed additional maps of parts of the area became available. Where possible, geology was plotted on topographic base maps; where these were lacking, aerial photographs were used as bases. Altogether seven different base maps, each on a different scale, were used. At present, the entire area is covered by the following topographic maps, to which all the geologic detail has been transferred by inspection, and photographically brought to a common scale $(1: 48,000)$ : the Springville, Spanish Fork, Spanish Fork Peak, Goshen Valley North, Soldiers Pass, and Lincoln Point quadrangles in the $7 \frac{1}{2}$-minute series; and the Provo, West Mountain, Santaquin, and Santaquin Peak quadrangles in the 15-minute series.
This report deals mostly with the geology of the unconsolidated deposits of Quaternary age. Historically, such deposits have been virtually neglected or treated only geomorphically, although, as pointed out by Hunt, Varnes, and Thomas (1953, p. 4, 5), their mapping involves the same principles as the mapping of bedrock formations. In this report, the stratigraphic approach is emphasized and in mapping, the following methods and criteria were used: separation of the deposits into mappable units; superposition of beds; lateral tracing of contacts between formations; and observation of lateral and vertical changes in lithology. Soil texture and composition, variations in ground drainage conditions and vegetation, and landforms were also used to identify deposits. Where natural exposures did not yield satisfactory information, trenching or augering was used to identify a unit or locate a contact.

In mapping, 18 inches was taken as the minimum thickness of deposits to be shown, following the usage in northern Utah Valley.

\section{PREVIOUS STUDIES}

Gilbert (1875, p. 88-104) first systematically studied the sediments and shorelines of the ancient lake to which he gave the name "Bonneville," in honor of the early explorer B. L. E. Bonneville. The fieldwork which formed the basis for Gilbert's monograph on Lake Bonneville (Gilbert, 1890) was begun in 1872 and continued intermittently until 1881 . He was first introduced to the study of the old lake during the field season of 1872 as a member of a topographic party of the Wheeler Survey. He served with that party until 1875, then joined the Powell Survey, also in Utah.

With Powell during 1875-78, he found many opportunities to continue his study of Lake Bonneville. When the U.S. Geological Survey was organized in 1879 , Gilbert was placed in charge of the Division of the Great Basin, with the understanding that the Quaternary lakes, studied previously as incidental to other work, should form a principal subject of study. The fieldwork of 1880 was confined to the Lake Bonneville basin, but after that Gilbert had little opportunity for field work in this area.

The first published map delineating the pattern of the Quaternary lakes of the Great Basin was compiled by the geologists of the 40th Parallel Exploration (King, 1878). The fieldwork of this party was restricted to a belt 100 miles wide, spanning the Great Basin in its broadest part. With this belt the approximate boundaries of the Quaternary lakes were mapped for the first time. King (1878) reported that Lake Bonneville was as much as 180 miles wide at about latitude $40^{\circ} 21^{\prime} \mathrm{N}$. and 300 miles long in a north-south direction. On the map accompanying his report King adopted the outline 
of the south half of Lake Bonneville from a map Gilbert made for the Wheeler Survey, but the north half was taken directly from the maps that Gilbert made for King.

Since the publication of Gilbert's monograph more than 70 years ago only a few works containing maps and geologic information on the Utah Valley area have been published. One of the earliest of these pertains to the underground water of the Utah Lake and Jordan River valleys, made more than 50 years ago by Richardson (1906). The sections pertaining to the Quaternary geology were adapted from Gilbert's reports.

A geologic map of Utah, published in color in 1920 (Butler and others, 1920), had a brief reference to Quaternary geology which likewise was adapted from the works of Gilbert.

The Lake Bonneville beds in the part of Goshen Valley adjoining the Tintic mining district were briefly mentioned by Lindgren and Loughlin, (1919). The map accompanying their report was the first of this area showing Lake Bonneville beds as separate from the Quaternary alluvium.

Lee (1924) discussed the geology and physiography of the Great Salt Lake basin, in which he included Utah Valley.

Nolan (1943) has summarized, and in places interpreted, the published information that was available to 1938 on the geology of the Basin and Range province.

The Quaternary sediments of the north half of Utah Valley have been studied and mapped in detail by Hunt and others (1953).

\section{ACKNOWLEDGMENTS}

It is a geniune pleasure to acknowledge the aid and encouragement of Charles B. Hunt during the fieldwork and writing of the report from January 1947 to the present. Without the benefit of Mr. Hunt's experience in the northern half of Utah Valley, I would not have been able to complete the mapping of the southern half, or this report, in time available.

A. C. Tester, professor of geology at the State University of Iowa, supervised the analysis of some of the sediments in the sedimentation laboratory at that University, and also critically read parts of the manuscript. Many thanks are due him for criticisms and stimulating discussions both in the field and office.

Appreciation is also due J. S. Jennings, Division of Soil Chemistry, Utah State Agricultural College; George H. Hansen, professor of geology, Brigham Young University; Roger B. Morrison, Gerald M. Richmond, A. A. Baker, and H. E. Thomas of the U.S. Geological Survey; J. Hoover Mackin, University of Washington; and J. Stewart Williams, Utah State Agricultural College.

\section{PHYSICAL GEOGRAPHY}

Utah Valley is an intermontane basin at the eastern margin of the Basin and Range province. It is bounded on the east by the lofty Wasatch Mountains, on the west by the Lake Mountains, the East Tintic Mountains and the intervening low hills, and to the north by the Traverse Range, but it opens to the south over a low pass to Juab Valley. The valley is interrupted by West Mountain, an elongated north-south ridge in the southcentral part that passes southward into Long Ridge, which forms part of the east border of the mapped area.

Utah Valley lies at the eastern margin of Lake Bonneville (fig. 23). The high-water level of the old lake in this area was at an altitude of about 5,135 feet; below this altitude lacustrine landforms predominate, including many conspicuous shore terraces, bars, spits, and deltas, in marked contrast to the entirely subaerial landforms above the high shore.

Utah Lake occupies the central part of the valley, averaging 8 feet in depth, and in a few places as much as 20 feet. The spillway of an artificial dam at its north end is at an altitude of 4,488 feet; normally the lake surface is 1 or 2 feet lower. The Jordan River drains the lake northward into Great Salt Lake. The lakeshores slope very gently in most places, and therefore slight fluctuations in water level cause large changes in lake area. The main body of Utah Lake is about 19 miles long in a north-south direction and 10 miles wide at its widest part, and it covers about one-fifth of the total mapped area. Provo Bay, east of Utah Lake and connected with it by a narrow channel, is about 3 miles long and 2 miles wide, and is mostly swamp with a few ponds.

A broad nearly level plain called the lake plain borders Utah Lake between Provo and West Mountain, and also west of West Mountain near Goshen. This plain slopes from less than 5 to 10 feet per mile and locally is marshy. Between the mountains and the lake plain or lakeshore are piedmont plains that slope valleyward from 50 to several hundred feet per mile. The most extensive piedmont plain borders the Wasatch Mountains. It generally is several miles wide, and merges with the lake plain along a line that passes a mile or less west of the principal towns from Provo to Santaquin. On this piedmont plain are various minor landforms. Most conspicuous are alluvial fans of pre- to post-Lake Bonneville age, and deltas, bars, spits, and shore terraces of Lake Bonneville. Most of the alluvial fans are of post-Lake Bonneville age; the largest, however, are of late Lake Bonneville (late Provo and Provo) age, built by the Provo River and by Hobble, Maple, Payson, and Summit Creeks. The towns of Provo, Springville, Payson, and Santaquin are situated on these fans. Large fans of pre-Lake 


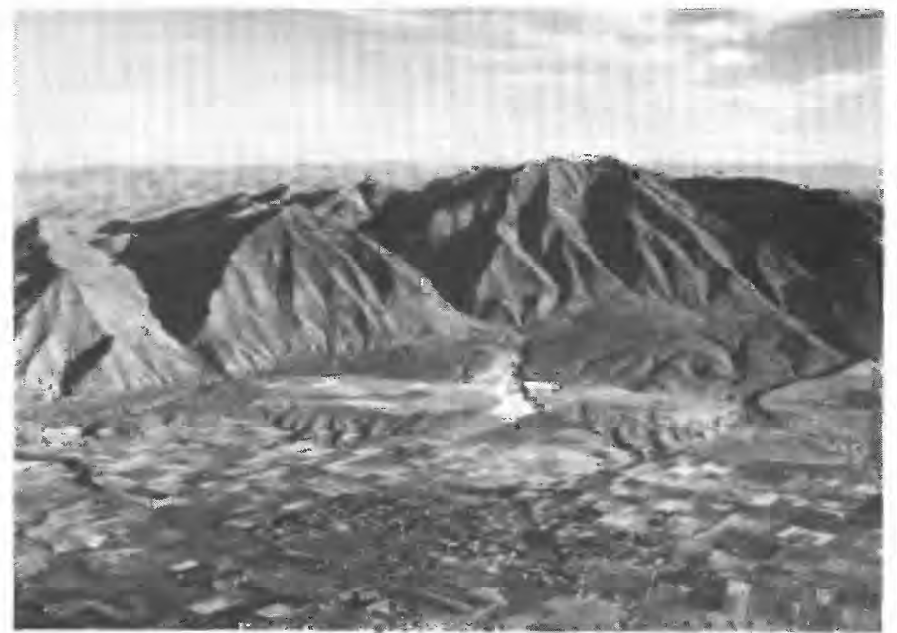

Figure 24.-Aerial view south of Salem showing pre-Lake Bonneville alluvial fan at the foot of the Wasatch Mountains cut by shoreline terraces of Lake Bonneville.

Bonneville age, deeply and maturely dissected, are exposed above the Bonneville shoreline south of Salem and Santaquin (fig. 24).

Deltas were built at the mouths of all the larger streams draining the Wasatch Mountains, especially the Provo River, Hobble and Maple Creeks, and Spanish Fork; by far the largest deltas were built while the lake stood at the Provo level. Uncommonly large bars and spits occur south and northeast of Payson and south and southwest of Santaquin.

Another piedmont plain extends along the western edge of the area to the Lake Mountains. It lacks deltas and the alluvial fans are tiny compared with those on the eastern piedmont.

\section{CHEMICAL QUALITY OF WATER IN UTAH LAKE}

The water of Utah Lake is derived not only from streams and seeps but also from thermal springs in its western part. Chemical composition of the water varies slightly from place to place and salinity has increased notably during the last 50 years (tables 1 , 2 ). The increase in salinity is due partly to the follow-

T $\mathrm{ABLE}$ 1.-Chemical analyses, in parts per million, of water in Utah Lake, 1883 to 1938

\begin{tabular}{|c|c|c|c|c|}
\hline Radical & $\begin{array}{c}1883 \\
\text { (Clarke, } \\
1884, \text { p. 29) }\end{array}$ & $\begin{array}{c}1899 \\
\text { (Cameron, } \\
1905, \text { p. 113) }\end{array}$ & $\begin{array}{c}1904 \\
\text { (Brown, in } \\
\text { Cameron, } \\
1905, \text { p. 113) }\end{array}$ & $\begin{array}{c}1933 \\
\text { (Decker } \\
\text { and Maw, } \\
\text { 1933, p. 36) }\end{array}$ \\
\hline $\begin{array}{l}\text { Calcium }(\mathrm{Ca}) \\
\text { Magnesium }(\mathrm{Mg}) \\
\text { Sodium }(\mathrm{Na}) \\
\text { Potassium }(\mathrm{K}) \\
\text { Sulfate }(\mathrm{SO})_{4} \\
\text { Chloride }(\mathrm{Cr}) \\
\text { Bicarbonate }\left(\mathrm{HC} \mathrm{CO}_{3}\right) \\
\text { Carbonate }\left(\mathrm{CO}_{3}\right) \\
\text { Silica }\left(\mathrm{SiO}_{2}\right)^{-}\end{array}$ & $\begin{array}{r}55.8 \\
18.6 \\
17.8 \\
130.6 \\
12.4 \\
60.8 \\
10.0\end{array}$ & $\begin{array}{r}67.6 \\
113.8 \\
233.7 \\
226.7 \\
316.5 \\
23.7 \\
\end{array}$ & $\begin{array}{r}67.7 \\
73.5 \\
207.2 \\
25.8 \\
333.9 \\
205.5 \\
24.0 \\
22.6 \\
22.4\end{array}$ & $\begin{array}{r}107.6 \\
46.9 \\
198.9 \\
33.4 \\
327.1 \\
284.5 \\
206.8 \\
10.0 \\
35.4\end{array}$ \\
\hline Total dissolved solids... & 306.0 & 892.0 & 983.6 & $1,250.6$ \\
\hline
\end{tabular}

ing: high sodium chloride content of the thermal-spring water; control of the lake by the dam at its northern end, which has raised the lake level and increased evaporation; certain saline inflowing streams, especially Currant Creek; and drainage from somewhat saline irrigated land near Goshen, Saratoga, and Lehi.

TABLE 2.-Chemical analyses, in parts per million, of six samples of water in Utah Lake, 1983

Analyses by L. B. Decker, unpublished M. S. thesis, Brigham Young Univ., 1933]

\begin{tabular}{|c|c|c|c|c|c|c|}
\hline Radical & 1 & 2 & 3 & 4 & 5 & 6 \\
\hline Calcium $(\mathrm{Ca})$ & 103.2 & 122.3 & 107.7 & 95.5 & 187.2 & 516.9 \\
\hline Magneslum (Mg) & 44.9 & 47.9 & 46.9 & 40.1 & 54.5 & 135.6 \\
\hline Sodium $(\mathrm{Na})$ & 132.5 & 212.8 & 196.9 & 249.3 & 221.7 & 932.1 \\
\hline Potassium (K) & 30.1 & 37.9 & 33.4 & 38.4 & 42.1 & \\
\hline Alumina $\left(\mathrm{Al}_{2} \mathrm{O}_{3}\right)-$ & 10.6 & 10.4 & 9.3 & 7.0 & 21.1 & Trace \\
\hline $\begin{array}{l}\text { Iron oxide }\left(\mathrm{Fe}_{2} \mathrm{O}_{3}\right)- \\
\text { Chloride }(\mathrm{Cl})^{-}\end{array}$ & 217.6 & 290.6 & 284.5 & 388.9 & 347. 7 & 1,275 \\
\hline Sulfate $\left(\mathrm{SO}_{4}\right)$ & 274.3 & 349.5 & 327.1 & 322.1 & 455.5 & $1,582.9$ \\
\hline Carbonate $\left(\mathrm{CO}_{3}\right)$ & 21.9 & 12.1 & 10.0 & 7.3 & & \\
\hline Bicarbonate $\left(\mathrm{HCO}_{3}\right)$ & 189.9 & 203.5 & 206.8 & 230.6 & 322.5 & 622.8 \\
\hline Silica $\left(\mathrm{SiO}_{2}\right)_{\ldots}$ & 37.4 & 29.4 & 35.4 & 33.1 & 9.7 & 16.0 \\
\hline Manganese $(M n)$ & .5 & .8 & .7 & Trace & .9 & \\
\hline
\end{tabular}

1. 11/2 miles northwest of the mouth of Provo River in Utah Lake; water $6 \mathrm{ft}$ deep, April 1933.

2. North end of Utah Lake; surface water directly over the Crater Springs near Saratoga, April 1933.

3. 2 miles east of sample 2 in Utah Lake; water $3 \mathrm{ft}$ deep, April 1933.

4. 1/4 mile southwest of Lincoln Beach, in Utah Lake; water $8 \mathrm{ft}$ deep.

5. Directly over Crater Springs; water $75 \mathrm{ft}$ deep.
6. Hot Springs at lakeshore, Lincoln Beach; water temperature $85^{\circ} \mathrm{F}$, April 1933.

Crater Springs (table 3) are in the northwestern part of the lake, and the hot springs at the Saratoga resort are a short distance westward at the lakeshore. Crater Springs were sounded by C. L. Swendson (in Richardson, 1906 , p. 49), of the U.S. Reclamation Service, who found 3 groups of springs, 100 square feet to 3 acres in area and 20 to 80 feet deep. The water from all these hot springs as well as from those at the Saratoga resort was $111^{\circ} \mathrm{F}$ in 1904 . These and other thermal springs in or near the lake, notably those near Rock Island and Lincoln Beach, contribute many thousands of acre-feet of water to the lake annually. Swendson (in Richardson, 1906, p. 24) concluded that between August 1903 and August 1904 ground-water inflow amounted to about 132,870 acre-feet of the total inflow of 471,140 acrefeet.

The average total dissolved solids (table 4) of the streams that are tributary to the lake is about $600 \mathrm{ppm}$

TABLE 3.-Chemical analyses, in parts per million, of water from thermal springs in or near Utah Lake

[Analyses by L. B. Decker, unpublished M. S. thesis, Brigham Young Univ., 1933]

\begin{tabular}{|c|c|c|c|c|c|c|c|c|c|}
\hline Source & 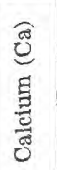 & 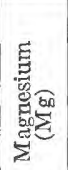 & 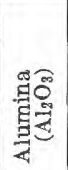 & 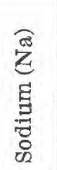 & 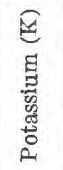 & 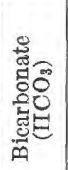 & 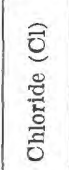 & 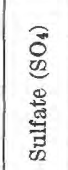 & 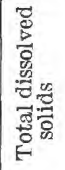 \\
\hline $\begin{array}{l}\text { Crater Springs } \\
\text { Lincoln Beach Spring } \\
\text { Saratoga Springs. }\end{array}$ & $\begin{array}{l}187 \\
516 \\
148\end{array}$ & $\begin{array}{r}554 \\
135 \\
34\end{array}$ & $\begin{array}{r}21 \\
\operatorname{Tr} . \\
18\end{array}$ & $\begin{array}{l}222 \\
932 \\
273\end{array}$ & 42 & $\begin{array}{l}322 \\
623 \\
281\end{array}$ & $\begin{array}{r}348 \\
1,273 \\
361\end{array}$ & $\begin{array}{r}455 \\
1,582 \\
388\end{array}$ & $\begin{array}{l}1,651 \\
5,061 \\
1,503\end{array}$ \\
\hline
\end{tabular}


TABLE 4.-Chemical analyses, in parts per million, of water of surface streams emptying into Uta h Lake 1

\begin{tabular}{|c|c|c|c|c|c|c|c|c|c|}
\hline Stream & 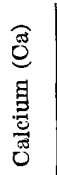 & 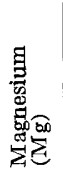 & 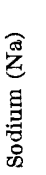 & 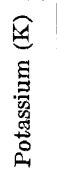 & 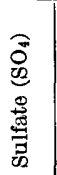 & 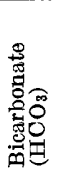 & 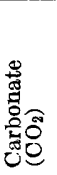 & $\begin{array}{l}\widehat{0} \\
\text { 号 } \\
\text { 葛 }\end{array}$ & 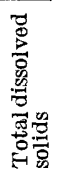 \\
\hline $\begin{array}{l}\text { 1. American Fork } \\
\text { 2. Payson Creek } \\
\text { 3. Currant Creek } \\
\text { 4. Santaquin Creek- } \\
\text { 5. Warm Creek- } \\
\text { 6. Spanish Fork } \\
\text { 7. Provo River }-. \\
\text { 8. Provo River } \\
\text { 9. Jordan River (out- } \\
\text { flow) }\end{array}$ & $\begin{array}{r}45 \\
12 \\
47 \\
12 \\
114 \\
68 \\
51 \\
71 \\
111\end{array}$ & $\begin{array}{l}24 \\
17 \\
54 \\
31 \\
48 \\
36 \\
29 \\
14 \\
13\end{array}$ & $\begin{array}{r}4 \\
22 \\
89 \\
31 \\
381 \\
46 \\
28 \\
19 \\
251\end{array}$ & $\begin{array}{r}10 \\
3 \\
44 \\
5 \\
92 \\
17 \\
22 \\
18\end{array}$ & \begin{tabular}{r|}
42 \\
32 \\
115 \\
33 \\
114 \\
64 \\
44 \\
74 \\
334
\end{tabular} & $\begin{array}{l}\mathbf{1 4 5} \\
121 \\
181 \\
212 \\
333 \\
277 \\
205 \\
146\end{array}$ & $\begin{array}{l}14 \\
15 \\
14 \\
28\end{array}$ & \begin{tabular}{r} 
Tr. \\
\hdashline 217 \\
\hdashline 703 \\
28 \\
28 \\
11 \\
378
\end{tabular} & $\begin{array}{r}270 \\
221 \\
762 \\
338 \\
1,818 \\
536 \\
407 \\
381 \\
1,087\end{array}$ \\
\hline
\end{tabular}

${ }^{1}$ Analyses 1-7 and 9 are from the Soils Survey of the Provo area, Utah: U.S. DeptAgriculture Bur. Soils, 1904, p. 22 .

(parts per million). Calcium is the most abundant base, magnesium is second, sodium third; potassium is present in very minor amounts. Carbonate is the most prominent acid radical, sulfate is second and in some cases almost equal to carbonate; chloride generally is present in small amounts, except in the water of Currant Creek, which has extensive salt deposits of Jurassic age at its headwaters. Warm Creek also is high in dissolved solids and chloride, for it rises in several somewhat saline warm springs along a fault zone at the base of Long Ridge east of Goshen.

\section{CLIMATE}

Southern Utah Valley is temperate and semiarid. The lofty Wasatch Mountains are a pronounced physiographic and climatic barrier that largely determines the local distribution of rainfall in the valley. The mountains have much lower temperatures and receive much more precipitation than the valley. The variations in altitude, together with changes of season, the northern latitude, and weather disturbances, have accounted for maximum temperatures slightly over $110^{\circ} \mathrm{F}$, and minimum temperatures as low as $-35^{\circ} \mathrm{F}$. In the eastern part of the valley, temperatures are lower but precipitation is somewhat higher than in the western part.

Climatic data obtained by the U.S. Weather Bureau in and adjacent to southern Utah Valley are summarized in tables 5,6 , and 7 .

\section{CULTURE AND ACCESSIBILITY}

White men are first known to have entered southern Utah Valley September 23, 1776. Padre Francisco Silvestre Velez de Escalante, Padre Francisco Atanasio Dominiguez, and Don Bernado de Miera y Pacheco, in addition to seven others and Indian guides entered Utah Valley by way of Spanish Fork Canyon. From a low hill on the south side of Spanish Fork River,
TABLE 5.-Annual precipitation at various weather stations in southern Utah Valley

\begin{tabular}{|c|c|c|c|c|c|c|}
\hline Year & $\begin{array}{r}\text { Provo } \\
\text { City } \\
\text { (Alt } \\
4,650 \mathrm{ft})\end{array}$ & $\begin{array}{l}\text { Maple- } \\
\text { ton (Alt } \\
4,890 \mathrm{ft} \text { ) }\end{array}$ & $\begin{array}{l}\text { Spanish } \\
\text { Fork } \\
\text { Canyon } \\
\text { (Alt } \\
4,711 \mathrm{ft})\end{array}$ & $\begin{array}{l}\text { Payson } \\
\text { (Alt } \\
4,637 \mathrm{ft})\end{array}$ & 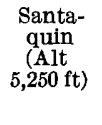 & $\begin{array}{l}\text { Elberta } \\
\text { (Alt } \\
4,650 \mathrm{ft})\end{array}$ \\
\hline 91. & $\begin{array}{l}10.81 \\
12.38\end{array}$ & & & & & \\
\hline & $\begin{array}{l}10.88 \\
\end{array}$ & & & & & \\
\hline & & & & & & \\
\hline 96 - & 51 & & & & & \\
\hline & $\begin{array}{l}{ }_{13.36}^{15} .36\end{array}$ & & & & & 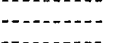 \\
\hline 9 & 15.77 & & & & & \\
\hline 00 & & & & & & \\
\hline 01. & $\begin{array}{r}11.21 \\
9.69\end{array}$ & & & & & \\
\hline & & & & & & 70 \\
\hline & & & & 16.80 & & \\
\hline 06 & 20 & & & 25. 62 & & \\
\hline & & 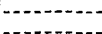 & $\cdots$ & $\begin{array}{r}20.12 \\
21.90\end{array}$ & & $\begin{array}{l}\text { 10. } 17 \\
\text { 12. } 91\end{array}$ \\
\hline & & & 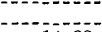 & 26. 18 & & 14.35 \\
\hline $1910_{1}$ & 12.55 & 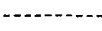 & 14.88 & 14.16 & & \\
\hline & $\begin{array}{l}17.12 \\
18.10\end{array}$ & $\begin{array}{l}16.42 \\
20.42\end{array}$ & $\begin{array}{l}16.30 \\
20.48\end{array}$ & $\begin{array}{l}18.79 \\
19.42\end{array}$ & & $\begin{array}{r}8.89 \\
10.89\end{array}$ \\
\hline & 19. 17 & & & 19.41 & & 13.00 \\
\hline & $\begin{array}{l}16.41 \\
16.98\end{array}$ & 21.60 & & 18. 17 & 20.38 & 13. 22 \\
\hline & & & & & 18.88 & \\
\hline & & 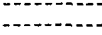 & & & 11 & \\
\hline & & $\ldots$ & & & & $\begin{array}{l}9.52 \\
10.59\end{array}$ \\
\hline $1920_{-}$ & $\begin{array}{l}14.08 \\
21.82\end{array}$ & 27.30 & $\begin{array}{l}17.41 \\
22.78\end{array}$ & $\begin{array}{l}15.78 \\
20.00\end{array}$ & $\begin{array}{l}1.28 \\
22.43\end{array}$ & $\begin{array}{l}10.59 \\
14.95\end{array}$ \\
\hline 1921 & 21 & 23. 14 & 67 & 1. & & $\begin{array}{l}12.43 \\
12.45\end{array}$ \\
\hline & & & & & & 10.00 \\
\hline & 11 . & & & & & 7.21 \\
\hline 1925. & 17. & 16.0 & 14 & 13 & 17.42 & 11. \\
\hline 1926. & 18. 71 & 22.46 & 17. 98 & 17.18 & 11. & \\
\hline & 18 & & & & & $\begin{array}{r}13.60 \\
7.78\end{array}$ \\
\hline & 14. & 18. & & & & 12.77 \\
\hline 00 & 14.12 & 18.40 & 19. & 16. & 20.06 & 11. \\
\hline & 8. 64 & & 14 & 10 & 15 & \\
\hline & 11. & & & & & 10. \\
\hline & 6. & & & & & \\
\hline & & & & & & 5. \\
\hline & & & 14. & 10.98 & 16.71 & \\
\hline & & & 19.51 & & & $\begin{array}{l}3.37 \\
0.91\end{array}$ \\
\hline & & 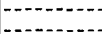 & & & & 12.54 \\
\hline & 9 & & & & & 6. \\
\hline 1940 & 15. & & 17.68 & 17. & 21.28 & \\
\hline 941 & $\begin{array}{l}\text { 21. } 60 \\
\text { 11. } 43\end{array}$ & $\ldots$ & $\begin{array}{l}22.09 \\
14.21\end{array}$ & $\begin{array}{l}18.98 \\
12.08\end{array}$ & $\begin{array}{l}29.82 \\
17.88\end{array}$ & $\begin{array}{r}14.28 \\
6.68\end{array}$ \\
\hline & $\begin{array}{l}12.61 \\
\text { S }\end{array}$ & & & & & 10.55 \\
\hline & 17. & $\ldots$ & $\begin{array}{l}18.72 \\
{ }_{23}\end{array}$ & 16.52 & $\begin{array}{l}18.87 \\
2207\end{array}$ & 10.52 \\
\hline & & & & & & \\
\hline & $\begin{array}{l}18.02 \\
12.44\end{array}$ & & $\begin{array}{l}20.25 \\
17.34\end{array}$ & 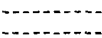 & $\begin{array}{l}\begin{array}{l}23.644 \\
19.34\end{array}\end{array}$ & $\begin{array}{l}\begin{array}{l}13.84 \\
11.665\end{array}\end{array}$ \\
\hline & & & 16.43 & 14.79 & 17.42 & \\
\hline
\end{tabular}

which they named Rio de Aguas Calientes, near the mouth of the canyon they saw Utah Valley and Utah Lake. They traveled north as far as the present site of Provo, thence west and camped on the shores of Utah Lake, which they referred to as Timpanogotzis, or Timpanoautizis (Auerbach, 1943, p. 64).

As early as 1811, but more so after 1820 , the fur trade brought many American and British trappers into the basin. Names like Jedediah S. Smith, James Bridger, Etienne Provost, and William H. Ashley stand out.

The Mormon pioneers entered the valley of the Great Salt Lake on July 24, 1847. In January 1849 
TABLE 6.-Monthly and annual mean temperatures in southern Utah Valley

[From U.S. Weather Bureau reports]

\begin{tabular}{|c|c|c|c|c|c|c|c|c|}
\hline Station & \multicolumn{2}{|c|}{$\begin{array}{l}\text { Number } \\
\text { of years }\end{array}$} & Jan. & Feb. & Mar. & Apr. & May & June \\
\hline $\begin{array}{l}\text { Provo } \\
\text { Spanish Fork } \\
\text { Santaquin. } \\
\text { Elberta. }\end{array}$ & $\begin{array}{l}-- \\
\cdots- \\
\cdots- \\
\cdots\end{array}$ & $\begin{array}{l}38 \\
21 \\
15 \\
27\end{array}$ & $\begin{array}{l}26.4 \\
28.6 \\
27.1 \\
26.8\end{array}$ & $\begin{array}{l}32.0 \\
34.0 \\
32.9 \\
32.1\end{array}$ & $\begin{array}{l}40.6 \\
41.9 \\
40.0 \\
40.5\end{array}$ & $\begin{array}{l}48.8 \\
50.5 \\
47.6 \\
49.0\end{array}$ & $\begin{array}{l}56.7 \\
59.0 \\
56.4 \\
57.4\end{array}$ & $\begin{array}{l}64.5 \\
68.4 \\
65.0 \\
67.2\end{array}$ \\
\hline Station & $\begin{array}{l}\text { Number } \\
\text { of years }\end{array}$ & July & Aug. & Sept. & Oct. & Nov. & Dec. & Annual \\
\hline $\begin{array}{l}\text { Provo } \\
\text { Spanish Fork } \\
\text { Santaquin } \\
\text { Elberta. }\end{array}$ & $\begin{array}{l}38 \\
21 \\
15 \\
27\end{array}$ & $\begin{array}{l}72.1 \\
75.6 \\
73.8 \\
74.7\end{array}$ & $\begin{array}{l}70.0 \\
70.3 \\
71.3 \\
72.6\end{array}$ & $\begin{array}{l}60.5 \\
64.5 \\
62.2 \\
62.7\end{array}$ & $\begin{array}{l}49.3 \\
51.3 \\
50.4 \\
50.5\end{array}$ & $\begin{array}{l}38.9 \\
41.1 \\
38.9 \\
38.2\end{array}$ & $\begin{array}{l}28.1 \\
29.5 \\
29.0 \\
27.7\end{array}$ & $\begin{array}{l}49.0 \\
51.2 \\
49.6 \\
50.0\end{array}$ \\
\hline
\end{tabular}

TABLE 7.-Highest temperature, lowest temperature, and prevailing wind direction in southern Utah Valley

[From U.S. Weather Bureau reports]

\begin{tabular}{|c|c|c|c|c|}
\hline Station & $\begin{array}{l}\text { Number } \\
\text { of years }\end{array}$ & $\mid \begin{array}{c}\text { Highest } \\
\text { tempera- } \\
\text { ture }\left({ }^{\circ} \mathrm{F}\right)\end{array}$ & $\begin{array}{c}\text { Lowest } \\
\text { tempera- } \\
\text { ture }\left({ }^{\circ} \mathrm{F}\right)\end{array}$ & $\begin{array}{l}\text { Prevailing wind } \\
\text { direction }\end{array}$ \\
\hline $\begin{array}{l}\text { Provo } \\
\text { Spanish Fork. } \\
\text { Santaquin } \\
\text { Elberta. } \\
\text { Utah Lake... }\end{array}$ & $\begin{array}{l}38 \\
21 \\
15 \\
27 \\
21\end{array}$ & $\begin{array}{l}110 \\
106 \\
100 \\
105 \\
104\end{array}$ & $\begin{array}{l}-35 \\
-19 \\
-16 \\
-28 \\
-25\end{array}$ & $\begin{array}{l}\text { Northwest. } \\
\text { Southeast. } \\
\text { Southwest. } \\
\text { North. } \\
\text { North-northwest. }\end{array}$ \\
\hline
\end{tabular}

Brigham Young sent a party of nine into Utah Valley to study the possibility of establishing fisheries near Utah Lake.

The first settlement seems to date from April 1849, when another Mormon party of 30 men moved into Utah Valley from Salt Lake City and began construction of Fort Utah about 2 miles west of the present site of Provo.

The area of this report lies entirely within Utah County and includes the southern part of Provo, third largest city in Utah, and all of the cities of Springville, Spanish Fork, and Payson, as well as the towns of Mapleton, Salem, Palmyra, Lake Shore, Benjamin, Spring Lake, Goshen, and Elberta.

Southern Utah Valley, inhabited for more than 100 years and the site of widely diversified agriculture and industry, is readily accessible throughout. Roads are numerous and good, so that automobiles can be driven within a mile or so of any part of the mapped orea. Combined U.S. Highways 50, 89, and 91 cross Utah Valley, and at Provo connect with U.S. 189. U.S. 6 connects with U.S. 89 and 91 at Santaquin, to serve Eureka and points west.

The valley is served by the Union Pacific and the Denver and Rio Grande Western railroads, and has two airfields, one west of Provo near the shore of Utah Lake, and the other a mile north of Spanish Fork.

\section{STRATIGRAPHY}

Southern Utah Valley is floored mostly by sediments deposited in Lake Bonneville and later lakes during the Quaternary period. Younger alluvium and eolian sand and silt locally overlie the lake deposits. Beneath the Lake Bonneville beds are several hundred feet of unconsolidated earlier Quaternary fluvial and lacustrine sediments, in places resting on late Tertiary(?) tuff and fresh-water limestone.

Precambrian, Paleozoic, Mesozoic, and Cenozoic sedimentary, metamorphic, and intrusive and extrusive igneous rocks are exposed in the mountains adjoining and within southern Utah Valley (Baker, 1947). These rocks were the source of the sediments now in the valley. The geology of the area studied is shown on plate 5 .

\section{- PRE-QUATERNARY ROCKS}

Precambrian rocks crop out in small areas in the mountains adjoining the valley, southeast of Santaquin, and also east of Provo. They were not studied in detail, but a reconnaissance indicated the presence of two units: an ancient sequence of crystalline gneiss, schist, granite, and pegmatite of unknown thickness, unconformably overlain by a younger sequence of quartzite, slate, phyllite, shale, and graywacke conglomerate, slightly more than 3,000 feet thick.

Rocks of Paleozoic age are the principal pre-Quaternary unit exposed, cropping out along the entire western front of the Wasatch Mountains, and also in West Mountain, Long Ridge, and the Lake Mountains. All the periods of this era are represented. The rocks consist of sandstone, shale, limestone, orthoquartzite, dolomite, and subgraywacke, totaling at least 45,000 feet in thickness.

Rocks of the Mesozoic era are exposed locally on Long Ridge and at the mouth of Spanish Fork Canyon. They consist of sandstone, shale, conglomerate, lava, and tuff, aggregating perhaps several thousand feet in thickness.

Nonmarine sedimentary rocks and lava flows of early to late Tertiary age crop out locally in the hills south of the Lake Mountains and on Long Ridge.

Two small outcrops of fresh-water marl, sand, tuffaceous sand, and pyroclastic material are assigned to the Salt Lake formation of Pliocene age. One is about a mile north of Payson near the road to Benjamin; the other is a mile west of Payson near the road to West Mountain. A road cut in the first outcrop reveals the following section: 
Section of Salt Lake formation in road cut north of Payson Top.

Gravel and sand; reworked from Salt Lake formation; probably a deposit of Lake Bonneville....................

Salt Lake formation:

Fresh-water limestone; porous.....................

Cemented tuff and tuff breccia, some pebbles and cobbles of quartzite

Volcanic pebbles and cobbles; grit matrix partly cemented with lime carbonate..........................

Sand and grit

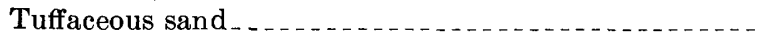

Base.

Feet 4

Insoluble residues in the beds consist of many resistant detrital minerals with quartz predominating and feldspar, chert, mica, basaltic hornblende, and, rarely, glass shards also present.

A lamprophyre dike, partly covered by the Lake Bonneville group, crops out in the foothills less than a mile southeast of Springville (NE $1 / 4$ sec. 34 , T. 7 S., R. 3 E.). Loughlin (1918, p. 101-109) has described two similar lamprophyre dikes in the southern Wasatch Mountains.

\section{QUATERNARY DEPOSITS IN THE MOUNTAINS ADJOINING SOUTHERN UTAH VALLEY}

The mountains bordering southern Utah Valley contain a variable thickness of till, outwash, alluvium, slope wash, talus and other colluvium, and soils. Some of this surficial material is pre-Lake Bonneville in age, some is coeval with the lake, and some is younger.

Moraines occur near cirque heads on the higher peaks of the Wasatch Mountains adjacent to the valley. Atwood (1909) mapped glacial drift and morainic ridges in North and South Forks, tributaries to Provo Canyon and on the southeast slope of Provo Peaks in the heads of Bartholomew and Whitmore Canyons at altitudes of 9,000 to 11,000 feet. He mentions that Spanish Fork Peak did not support a glacier, but was affected by snowslides and névé. Both the moraines and the surviving outwash trains are well above the high-water mark of Lake Bonneville.

\section{QUATERNARY DEPOSITS IN SOUTHERN UTAH VALLEY}

PRE-LAKE BONNEYILLE FAN GRAVEL

Huge alluvial fans of pre-Lake Bonneville age extend far into the valley from the bordering mountains (fig. 24). Their form commonly is well preserved, but some fans, especially faulted ones, have been dissected to a series of hills. The largest and thickest of these fans border the Wasatch Mountains, but extensive ones flank the East Tintic Mountains, the Selma Hills, Mosida Hills, Lake Mountains, and Cedar Valley Hills. Pre-Lake Bonneville fan gravel forms a thin veneer on hard-rock pediments around West Mountain and the east side of Lake Mountains.

The fans consist of boulder gravel in places (with boulders several feet across) to pebble gravel and locally sand. Exposures showing internal structure are rare; in them bedding generally is weak to obscure, sorting fair to very poor, and the gravel angular to subrounded. Locally, some beds are fairly well bedded and moderately well sorted. The surfaces of the fans and the bedding in them slope several hundred feet per mile basinward. The fan gravel is obviously the result of deposition by streams subject to heavy floods. The best exposure of pre-Lake Bonneville fan gravel is a deep gully in the area called the Goose Nest, southeast of Payson. In Santaquin and Pole Canyons 300 to 350 feet of this gravel is exposed.

These fans are older than Lake Bonneville for the high-water mark of the lake is impressed on them (fig. 24), and the lake deposits, even the earliest, overlap the fans. South of the Utah County Infirmary (south of Provo) a pre-Lake Bonneville fan, bearing eroded pre-Lake Bonneville soil, is locally exposed beneath the oldest sediments of Lake Bonneville, and it also can be traced farther basinward beneath the lake sediments by data from well logs. In a gully south of Salem, pre-Lake Bonneville fan gravel can be traced northward beneath the Lake Bonneville group. At the north end of Little Mountain, south of Payson, pre-Lake Bonneville fan gravel is overlapped by the Lake Bonneville group, which forms shore terraces, bars, and a spit.

The pre-Lake Bonneville fan gravel locally bears a Calcic Brown soil, which is far more strongly developed than any of the younger soils. Its upper limeleached, clay-enriched B horizon is reddish brown, locally as much as 7 feet thick, and the underlying calcareous (Cca) horizon, of strong calcium carbonate (caliche) concentration, is commonly 6 to 8 , and locally 10 feet or more thick. The best exposures of this old soil are south of Salem against the north base of Loafer Mountain. This soil occurs on the youngest beds of the pre-Lake Bonneville fan gravel and is overlapped by the oldest beds of the Lake Bonneville group. It probably formed just before the first rise of the lake. This ancient soil (paleosol) has been studied by Hunt and Sokoloff (1950), who noted its pre-Wisconsin age.

\section{LAKE BONNEVILLE GROUP}

Lake Bonneville covered about 20,000 square miles in western Utah and at its highest stage had a maximum depth of about 1,000 feet; its highest shoreline is about 5,135 feet above mean sea level. Utah Valley was a bay along the eastern part of the ancient lake. 
The sediments of this lake constitute the Lake Bonneville group, which is divided into three formations: Alpine (oldest), Bonneville, and Provo (youngest).

\section{ALPINE FORMATION}

The Alpine formation was first named and defined by Hunt (Hunt and others, 1953, p. 11). The type locality is the low hills surrounding the town of Alpine in northern Utah Valley. Gilbert (1890, p. 155-158) referred to these beds in part as "Intermediate," but as Hunt (Hunt and others, 1953, p. 17), noted, this term refers not to the stratigraphic position of sediments formed during the early history of Lake Bonneville but to their intermediate altitude between the Bonneville and Provo shorelines.

This formation overlies the pre-Lake Bonneville fan gravel and pre-Lake Bonneville soil. It is divided into four members-gravel, sand, silt, and clay-which are lithotopes. Each member is named from its prevailing texture but is not a homogeneous unit: the silt member, for example, also locally contains some clay and sand.

Outcrops of the Alpine formation border all the mountains; they are especially prominent along much of the east side of the valley, from south of Mapleton to the mouth of Spanish Fork Canyon. Here it is thickest, forming embankments 100 to as much as 335 feet high. It is mostly silt and clay, but sand and gravel are locally abundant in deltas, spits, and embankments near the mouths of streams. In some areas, notably in the southern end of the valley west and south of Santaquin, the formation is practically all silt and clay.

Sorting and stratification generally are very good to excellent, bedding is distinct, and individual beds are commonly only a few millimeters thick. Fresh exposures are light brown (Munsell color notation $5 Y R$ $6 / 4$ to $5 Y R 5 / 6)$, dark yellowish orange $(10 Y R 6 / 6)$, and moderate yellowish brown (10YR 5/4); but many beds become stained deeper yellow with hydrous iron oxide on weathering. The beds are nearly horizontal where they abut against the sloping surface of preLake Bonneville fans or bedrock. The basinward parts of these beds commonly are eroded; if projected, they would extend above the present valley surface.

The Alpine formation is especially well exposed in a fault scarp east of Mapleton, between Hobble Creek and Maple Creek canyons, where the following stratigraphic section, representative of the formation where it abuts against the Wasatch Mountains, was measured:
Stratigraphic section of the Alpine formation adjacent to the Wasatch Mountains between Hobble Creek and Maple Creek canyons, $S W^{1 / 4} N E^{1 / 4}$ sec. 12, T. 8 S., R. 3 E.

Colluvium and soil.

Bonneville formation: Cobble and boulder gravel._._._._. 35

Disconformity; weak soil.

Alpine formation:

Silt, medium- to coarse-grained; gray brown $(5 Y R 3 / 2)$ to moderate yellowish brown $(10 Y R 5 / 4)$ fresh, lightbrown $(5 Y R 5 / 6)$ to dusky yellow $(5 Y 6 / 4)$ on weathered surface; composed of angular to subangular fragments of quartzite, limestone, and sandstone; well sorted, finely laminated. A few thin lenses of pebble

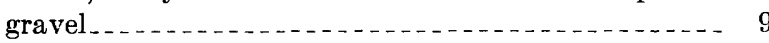

Silt, coarse-grained, with a few beds of very fine sand; pale gray to gray brown; well sorted; well bedded. Composed primarily of subangular grains of quartzite. A few clay bands contain finely divided mica on bedding planes. Some layers of well-sorted pebble and cobble gravel...................................

Gravel interbedded with sand and some silt; wellsorted granule, pebble, cobble, and small-boulder gravel. Sand and silt, interbedded; beds $1 / 2$ to 6 in. thick, well-sorted ................

Sand lenses, coarse-grained, gray to brown ..........

Gravel, granules to 3 -in. pebbles, subrounded to subangular; well-sorted layers interbedded with gravel

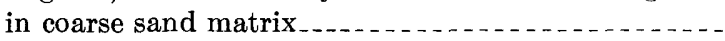

Silt, medium-grained, excellently sorted in alternating very light gray (5YR N8) beds to light-brown ( $5 Y R$ $6 / 4$ ) beds, $1 / 2$ to $4 \mathrm{in}$. thick. A few lenses of very fine grained sand, also some beds of very fine sand and coarse silty sand, highly crossbedded, $1 / 2$ to $1 \mathrm{ft}$. thick; a few beds of silty clay, very light gray, $1 / 2$ to

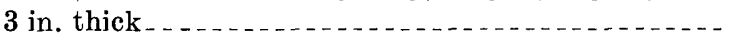

Sand, coarse- to medium-grained, highly crossbedded, with granule-sand intercalations and scattered clay bands one-half inch thick; most beds are light brown. Sand is finer near top of unit.......

Silt, coarse-grained, light-brown to pale-yellowishbrown (10YR 6/2), excellently sorted, composed of quartzite, dark chert, and limestone fragments which are subrounded to subangular. . .

Total Alpine formation (base not exposed) _. _ _. 335

Southward from this locality the beds of the Alpine dip basinward $1^{\circ}$ to $5^{\circ}$.

Well $\operatorname{logs}$ indicate that in the interior of the valley near Provo the Alpine formation is about 150 feet thick, but it thins northward. At the Columbia-Geneva Steel Co. plant at Ironton (south of Provo) the formation is about 150 to 160 feet thick. Commonly it is almost all clay farther west in the valley, but some wells penetrated beds of gravel and sand. At the Geneva Steel Co. plant, northwest of Provo, the boundary between the Lake Bonneville group and preLake Bonneville sediments is 105 feet below the surface (Hunt and others, 1953, p. 15, 16). These data indicate that the Alpine has thinned markedly northward 
from the vicinity of Mapleton. Even at the type locality near Alpine the total thickness of the Alpine probably does not exceed 125 feet.

GRAVEL MEMBER

The gravel member of the Alpine formation is subdivided into delta, beach, bar, and spit deposits, which differ principally in shape, topographic form, and distribution, and only in minor details in lithology. One type may overlap another and indicate relative age; for example, bar deposits commonly overlap beach deposits, signifying that the bar gravel was laid down soon after the beach gravel.

Most of the gravel deposits flank the Wasatch Mountains, reflecting the fact that all the perennial streams are on the eastern side of Utah Valley.

Individual beds of the member are well to poorly sorted. Most pebbles are subrounded to subangular; a few are well rounded. The average deposit consists of small cobbles to medium-sized boulders in a matrix of well-sorted coarse sand. Bedding ranges from indistinct to good and graded bedding is common. Exposures showing typical lithology can be seen in secs. 12 and 13 , T. 7 S., R. 3 E., near the mouth of Maple Canyon.

Mechanical analyses of the cobble and boulder gravel were made by marking off with chalk or string a representative unit area on the wall of an excavation. The unit area, about a yard square, was sampled by removing the separate pebbles, cobbles, and boulders, as well as the finer grained matrix, along grid lines. These samples were quartered and sieved through screens having the following openings: 2 inches, $1 \frac{3 / 4}{4}$ inches, $1 \frac{1 / 4}{4}$ inches, 1 inch, $1 / 2$ inch, $1 / 4$ inch, and $1 / 8$ inch, conforming to the size grades used by the Utah State Highway Commission. The screened samples were weighed and the results are shown in table 8 .

$\mathrm{T}_{\mathrm{ABLE}}$ 8.-Mechanical analyses of six samples of the gravel member of the Alpine formation

[Percentage weights from screen analyses of beach, bar, and delta subspecies]

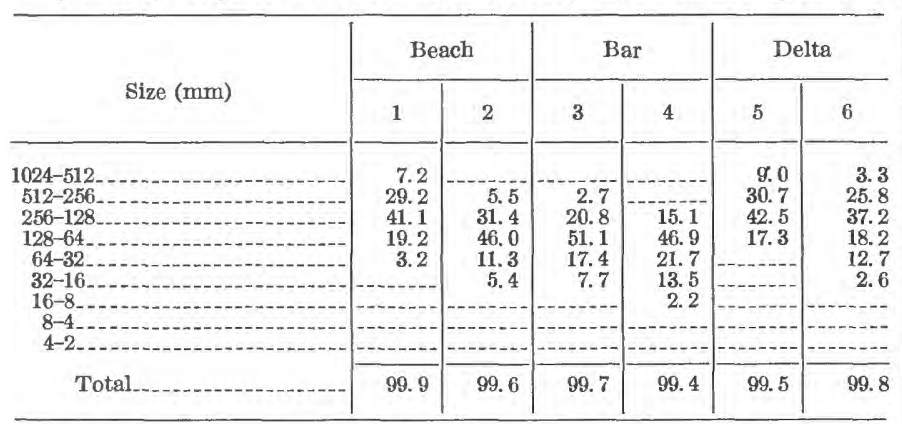

1. Gravel pit at base of Buckley Mountain in the NE1/4 SW $1 / 4$ sec. $21, T .7 \mathrm{~S}$, R. 3 E. 2. East of Provo, below Maple Flat.

3. South of Salem.

4. East base of Lake Mountain.

Mouth of Spanish Fork Canyon.

West of Elberta.
The contact of the gravel and sand members is gradational, especially where the beds are thick and intertonguing. Within individual beds the gradation commonly is within a few feet laterally.

At the base of the gravel member commonly is a thin discontinuous breccia layer of compact well-cemented poorly sorted blocks, slide rock, gravel, and commonly lime-cemented sand. At some localities, notably the north end of West Mountain and near the base of Long Ridge southwest of Goshen, the breccia consists of angular and subangular fragments which probably accumulated as talus below rock ledges contiguous to the ancient lake. Where the gravel member overlaps pre-Lake Bonneville fan gravel, the breccia consists of reworked fan gravel, generally buried beneath embankments of normal gravel of this member. The breccia is well exposed along the west base of Buckley Mountain, especially in the $\mathrm{SE} / 4 / 4$ sec. 21 and the $\mathrm{NE} / 4$ sec. 28 , T. 7 S., R. 3 E.

A nearly continuous gravel bay bar of this member south of Salem at an altitude of 5,100 feet is $3 \frac{5}{8}$ miles long, averaging 200 feet in width, and rising an average of 10 to 30 feet ( $65 \mathrm{ft}$ maximum) above the contiguous lake beds. Gravel pits expose some of its internal structure, texture, and composition. Foreset beds dip as much as $10^{\circ} \mathrm{N}$. (basinward). The gravel is strikingly imbricated-in one pit near the west end of the bar about 80 percent of the pebbles and cobbles are disc shaped; the ratio of thickness to width to length is commonly $1: 3: 5$.

A prominent spit of this member extends northward from the base of Little Mountain, forming a ridge along the eastern part of Payson. Other spits occur on the west side of West Mountain.

A moderately well preserved musk ox skull was collected from a sand lens in the gravel northeast of Santaquin. C. L. Gazin, of the U.S. National Museum, identified it as a member of the extinct genus Symbos, a long-ranging Pleistocene form.

\section{SAND MEMBER}

Most of the sand member of the Alpine formation overlaps the gravel member, for boulders, cobbles, and pebbles were deposited first in the littoral zone and then were covered by sand and finer clastics. The sand locally forms fairly prominent outcrops, but much of it has been eroded. Bar deposits are few: One is south of Salem and two small ones are south and west of Elberta.

The beds are commonly somewhat lenticular, and have high dips in foreset layers, locally as much as $12^{\circ}$. Sorting commonly is good to very good, although some beds are poorly sorted. Although mostly fine to very coarse sand, the member contains lenses of granules, 
pebbles, cobbles, and locally, thin layers of silt and clay. Some embankment deposits are finely laminated and consist mostly of fine sand with some admixed silt and clay. Locally, the grains are coated with iron oxides, especially along bedding planes of coarse sand beds in the bar deposits. Locally, the bedding is undulatory with broad, shallow oscillation ripple marks that are nearly symmetrical.

\section{SILT MEMBER}

The silt member is greater both in volume and areal distribution than the other members. It commonly crops out as prominent embankments above the Provo shoreline, particularly against the Wasatch Mountains. These embankments characteristically are nearly flat topped, but slope gently valleyward. They are best formed in five general areas: the broad, rather flat bench on both sides of the mouth of Spanish Fork Canyon south of Mapleton, the broad bay south of Salem, the narrow valley west and south of Santaquin, the large reentrant south of Elberta near the northern foothills of Long Ridge, and the piedmont east of the East

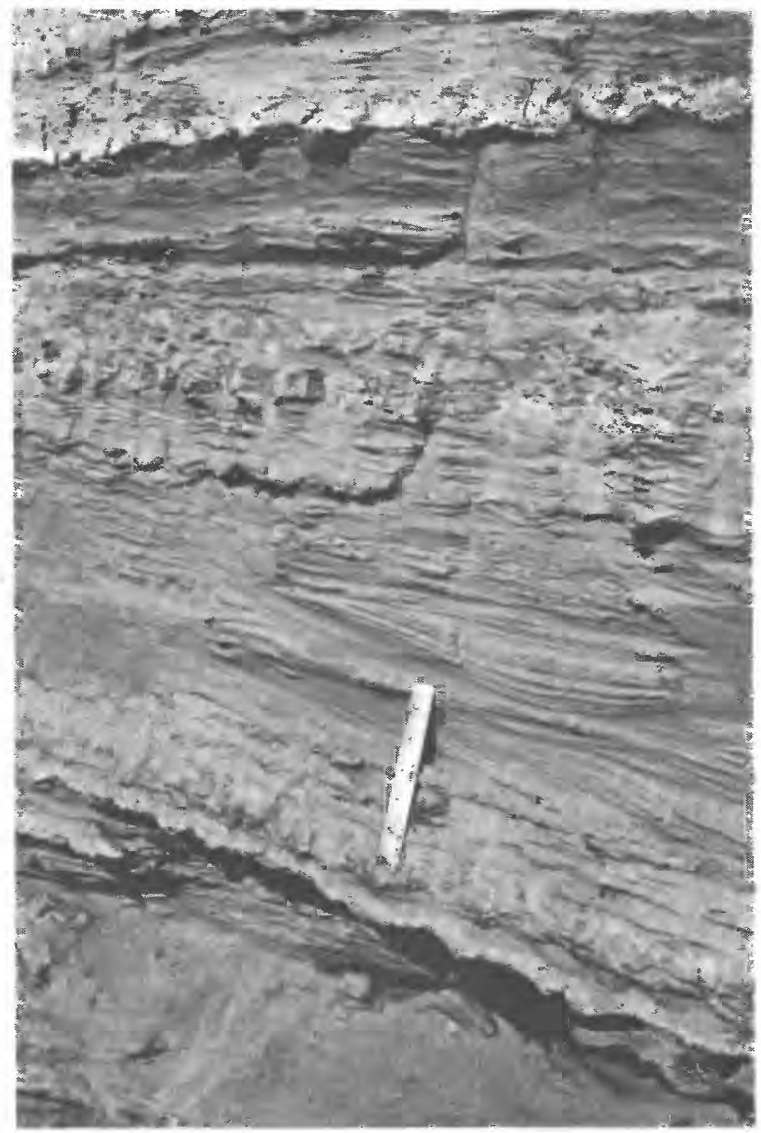

FIGURE 25.-Details of bedding in the silt member of the Alpine formation, showing layers of fine sand, silt, and clay. North side of the mouth of Slate Canyon. Ruler is 6 inches long.
Tintic Mountains. Some of the best exposures, though small, occur east of Springville, in the $\mathrm{SW}_{1 / 4}^{1 / 2} \mathrm{NE} / 4 / 4$ sec. 34, T. 7 S., R. 3 E.

As in northern Utah Valley (Hunt and others, 1953, p. 20) the silt member is, for the most part, thinly and evenly bedded and commonly intimately intercalated with sand and clay (fig. 25). Individual beds are $1 / 8$ to 2 inches thick and are composed of silt, sand, and locally grit, in alternating layers, with silt predominating. Locally, the bedding is gently undulating, suggestive of minor oscillation-type ripples. Streaks of iron oxide along the bedding planes produce rust-colored outcrops. The silt beds generally are well jointed and show blocky weathering, tending to form almost vertical-faced ledges. Some ledges overhang, especially where interbedded with uncemented sand or granule gravel.

In places the laminations are fine enough to suggest varves (fig. 26). As many as 65 clay layers separated by layers of silt or very fine sand have been observed in a section only 60 inches thick. Individual silt laminae less than half a millimeter thick have been traced horizontally as much as 20 feet. Foreset beds,

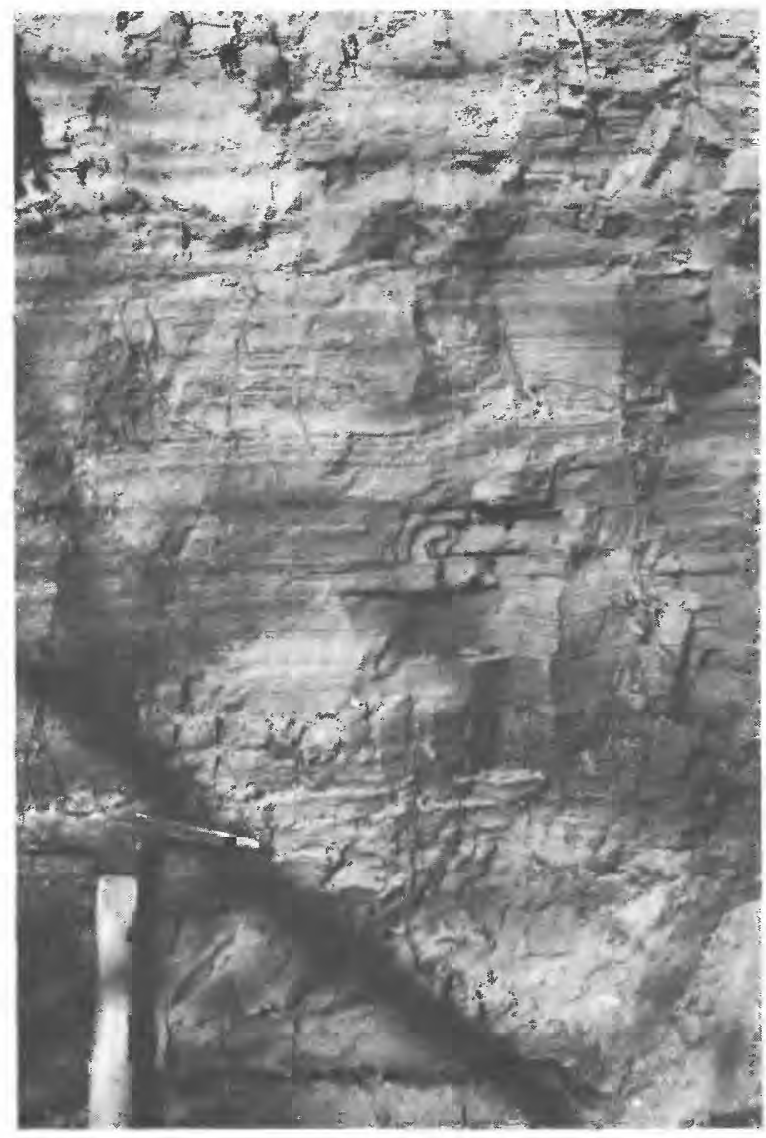

Frgure 26.-Finely laminated varvelike silt and clay in the Alpine formation. North of Maple Canyon in the central part of sec. 12, T. 8 S., R. 3E. 
locally present, meet the normal beds at acute angles. They dip steeply and uniformly toward the valley, in places as much as $27^{\circ}$. Mechanical analyses of the silt member are presented in table 9 .

TABLE 9.- Mechanical analyses of eight samples of the silt member of the Alpine formation

[Percentage weight from screen analyses; collected at different places between Provo and Santaquin]

\begin{tabular}{|c|c|c|c|c|c|c|c|c|}
\hline Size (mm) & 1 & 2 & 3 & 4 & 5 & 6 & 7 & 8 \\
\hline $\begin{array}{r}1 / 16-1 / 32 \ldots \\
1 / 62-1 / 64 \ldots \\
1 / 64-1 / 128 \\
1 / 128-1256\end{array}$ & $\begin{array}{r}65.6 \\
17.1 \\
12.5 \\
4.0\end{array}$ & $\begin{array}{r}8.8 \\
74.2 \\
12.3 \\
4.1 \\
\end{array}$ & $\begin{array}{r}19.5 \\
50.2 \\
23.7 \\
6.3\end{array}$ & $\begin{array}{r}9.9 \\
33.3 \\
53.7 \\
2.6\end{array}$ & $\begin{array}{r}7.5 \\
45.9 \\
36.2 \\
9.8\end{array}$ & $\begin{array}{r}11.6 \\
69.8 \\
12.6 \\
5.8\end{array}$ & $\begin{array}{r}21.7 \\
68.1 \\
8.4 \\
1.4\end{array}$ & $\begin{array}{r}9.0 \\
72.7 \\
14.3 \\
3.6\end{array}$ \\
\hline Total & 99.2 & 99.4 & 99.7 & 99.5 & 99.3 & 99.8 & 99.6 & 99.6 \\
\hline
\end{tabular}

These silt beds overlap steep to gently inclined surfaces on pre-Lake Bonneville fan gravel or bedrock. In places a layer of lake gravel underlies the silt, but commonly the passage from fan gravel or bedrock to silt is within a few inches; in many places the pre-Lake Bonneville soil is preserved with little erosion. These features indicate a rarity of strong waves, in contrast to conditions in Bonneville and Provo time. Probably stong windstorms were infrequent, and perhaps the lake was often covered with ice.

\section{CLAY MEMBER}

The clay member is not exposed in areas large enough to map, but well logs reveal that it is the most extensive member of the Alpine formation in the subsurface. The only good exposure is south of Salem near the canal along the 4,800-foot contour in the west-central part of sec. 13, T. 9 S., R. 2 E.

Typically the clay is plastic and mostly blue gray, but it ranges from cream white to very dark blue gray, depending mainly on the content of organic matter. Commonly it is very thinly laminated and varvelike in fresh exposures. Some laminae are less than $0.1 \mathrm{~mm}$ thick and can be traced laterally for scores of feet. The laminae contrast sharply in color with adjacent layers.

Most of the material assigned to the clay member is of clay size (Lane and others, 1947, p. 936-938), but probably much of the sediment is rock flour, judging from the absence of identifiable clay minerals in several samples analyzed by differential thermal methods. A few samples analyzed for size-grade distribution by the pipette method indicate that this member ranges from fine silt to medium-sized clay.

Some cores obtained at Ironton were analyzed for size-grade distribution and organic content. The organic matter is 1.6 to 2.3 percent on a dry-weight basis, as determined by the method devised by Dixon (1934, p. 739-743). Ferrous iron generally is present. The organic matter may prevent oxidation of the ferrous iron, and the dark color may be partly due to the iron.
Insoluble residues obtained from the cores and from outcrops of the clay have a few glass shards and flakes of biotite. These may have been reworked from the Salt Lake formation or may have come from volcanic ash falls during Alpine time. Total soluble material of the clay is commonly 68 to 70 percent, but values from 57 to 73 percent are not uncommon. In some samples the high soluble content is due to abundant ostracode carapaces.

The total thickness of the clay member as originally deposited near the mountains is not known because most of it has been eroded. Well-log data indicate that it is as much as 170 feet thick in the subsurface of the basin interior

DISCONFORMITY, LOESS, ALLUVIUM, AND SOIL OF INTER-ALPINE AND BONNEVILLE AGE

In places the Alpine is separated from the Bonneville formation by a disconformity representing subaerial erosion, a submature soil, and a few inches to several feet of loess and alluvium. These features indicate a post-Alpine, pre-Bonneville recession of the lake. They are best shown south and southwest of Santaquin (secs. 9, 10, 11, 14, 15, 16, 21, and 22, 'T. 10 S., R. 1 E.), where they occur locally beneath bars and spits of gravel of the Bonneville formation, ranging from altitudes of about 5,100 to 4,840 feet over silt and clay of the Alpine (figs. 27, 29,30). Several small spits southwest of Santaquin formed across a small valley which was eroded into silt of the Alpine. The inter-Alpine and Bonneville disconformity, loess, alluvium, and soil also are locally exposed in gullies on the piedmont east of the East Tintic Mountains. The lowest altitude in southern Utah Valley at which these features have been observed is about 4,840 feet.

\section{BONNEVILLE FORMATION}

The term "Bonneville formation" is used in this report somewhat differently than it was first defined by Hunt (Hunt and others, 1953, p. 20). As defined by Hunt, it includes "those deposits that accumulated in the lake during its highest stage, the stage that Gilbert (1890, p. 93-125) referred to as the Bonneville stage." Hunt clearly implies that the Bonneville formation was deposited while the lake surface was at, or very near, the level of the Bonneville shoreline. As used here, the Bonneville formation includes all the lake sediments that overlie the Alpine and are older than the Provo formation; locally, the Alpine and Bonneville formations are separated by a disconformity and subaerial deposits. Thus, the Bonneville formation includes not only lake sediments of the Bonneville shoreline zone, but also local shore and offshore deposits at lower altitudes. The latter includes both sediments laid down while the lake rose from the inter-Alpine and Bonneville minimum to 
the Bonneville maximum and while it regressed to the Provo shoreline level.

The Bonneville formation is much smaller in volume and outcrop area than the Alpine and Provo formations. It is exposed mainly as a narrow discontinuous band of gravel along the Bonneville shoreline, at an altitude of about 5,135 feet, where it generally is thickest, but it has been mapped as low as about 4,720 feet. It is best exposed along the base of the Wasatch Mountains, almost completely encircling West Mountain, near Santaquin in small isolated patches on the west and north slopes of Long Ridge, along the east base of the East Tintic Mountains, and on the south, west, and east sides of Lake Mountains. At these places the formation is largely shingle gravel a few feet to 35 feet thick, with internal structure like that in embankment gravel of the Alpine and Provo formations.

In places the formation includes sand, but sand is not extensive enough to be mapped separately. Offshore silt and clay are locally recognizable in outcrop but not mappable. The formation generally cannot be definitely identified in well logs.

Commonly the Bonneville formation overlies sand or silt of the Alpine formation (figs. 27, 29, 30). At some localities, however, gravel of the Bonneville rests directly on gravel of the Alpine formation. Although both gravel deposits are composed of similar rock types, the gravel of the Alpine grades laterally into sand, silt, or clay, whereas the Bonneville formation commonly is gravel throughout. In the Bonneville formation cobbles predominate, boulders and pebbles are subordinate, and finer clastics are present in very minor amounts except as matrix for the gravel. Further, gravel of the Bonneville formation typically is less well sorted into boulder, cobble, and pebble beds than gravel of the Alpine (fig. 28).

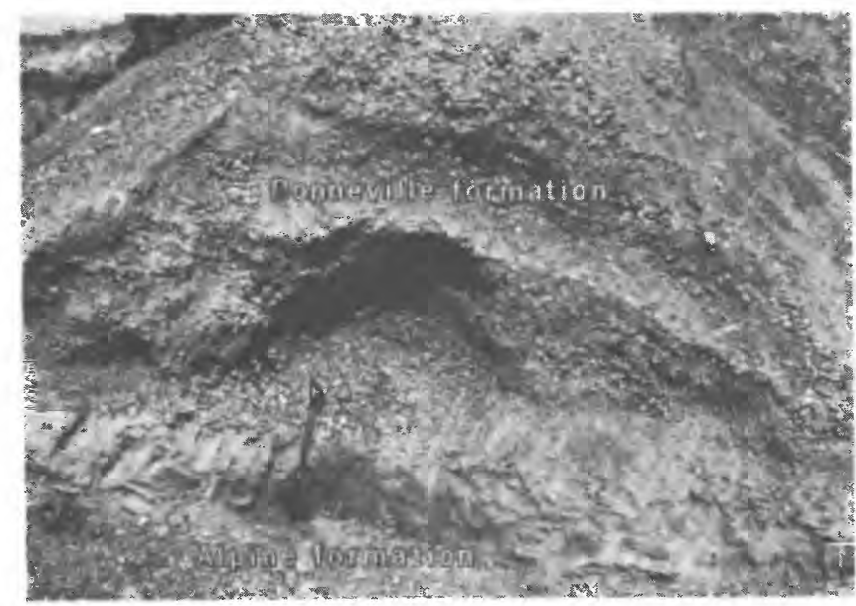

FIGURE 27.-Gravel of the Bonneville formation resting disconformably upon silt of the Alpine formation. Excavation in a bay bar south of Salem.
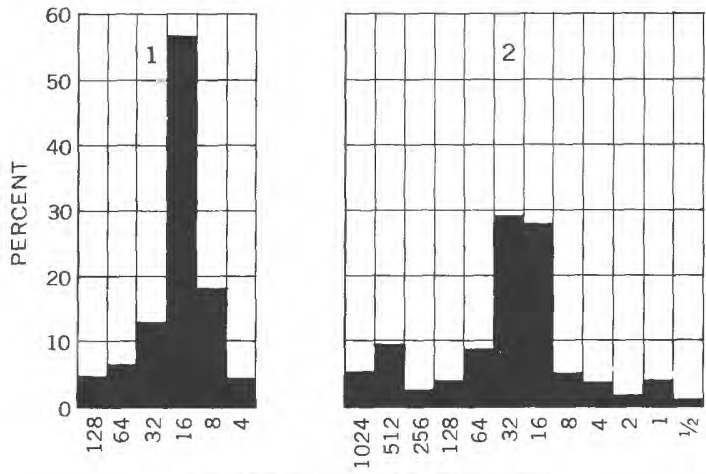

DIAMETER, IN MILLIMETERS
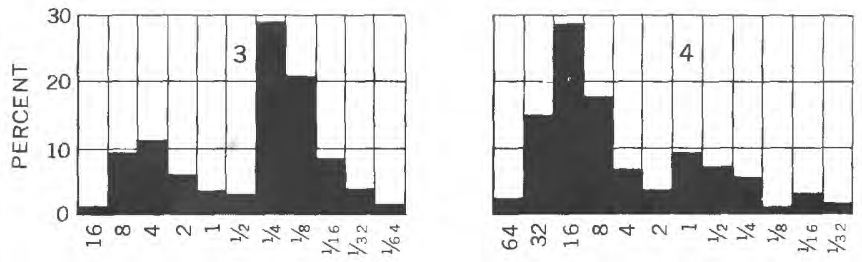

DIAMETER, IN MILLIMETERS

Figure 28,-Bar graphs of mechanical analyses of gravel from the Bonneville formation. 1, Gravel pit about 1 mile south of Slate Canyon (NE1/4 sec. 17, T. 7 S., R. 3 E.). 2, Gravel pit east of Springville (N E1/4 sec. 34, T. 7 S., R. 3 E.). 3, Bar west of Santaquin (SE1/4 sec. 3, T.10 S., R.1 E.). 4, Outcrop at the west side of West Mountain (sec. 16, R. 9 S., R. 1 E.).

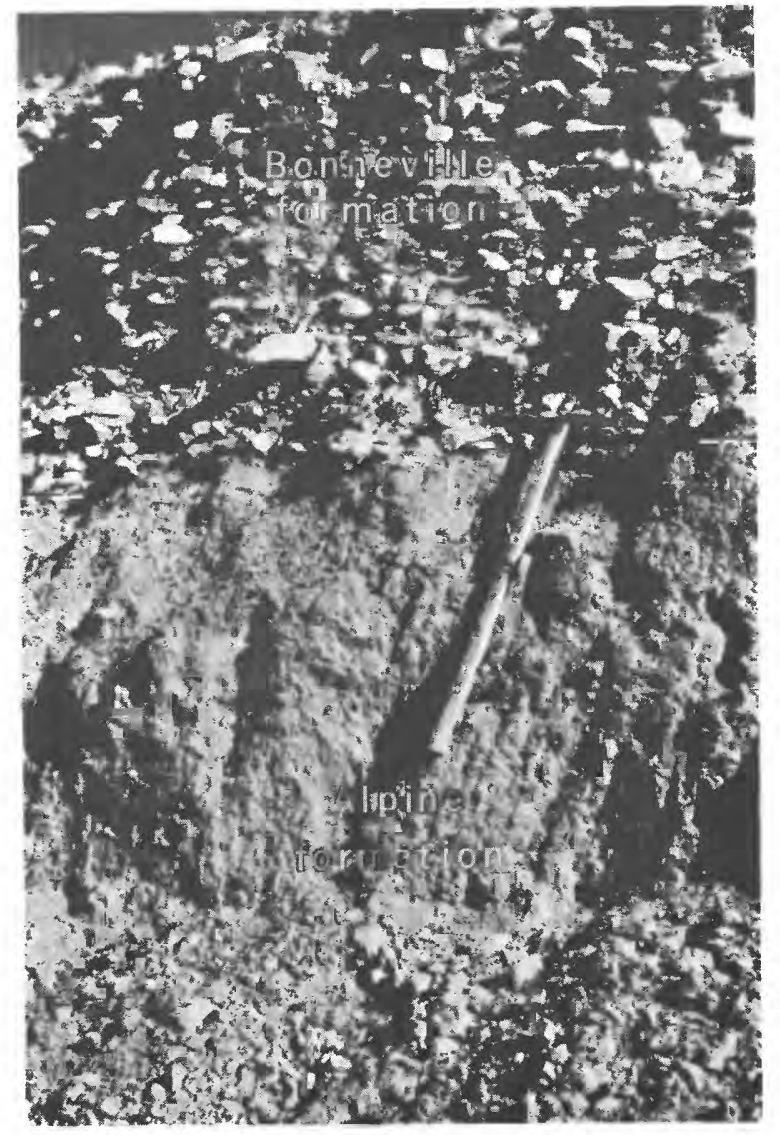

FIGURE 29,-Disconformity (just below pick head) between the Alpine and Bonneville formations east of Springville. 


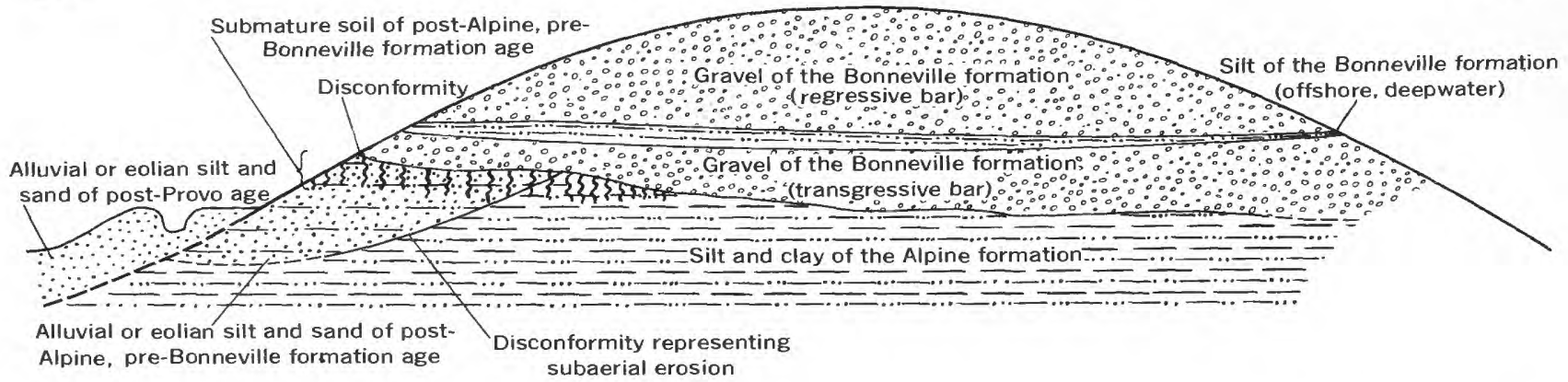

FIGURE 30.-Diagrammatic sketch of an exposure along a railroad cut about 500 feet long in the south-central part of sec. 3 , T. 10 S., R. 1 E. Alluvium or loess of interAlpine and Bonneville age, bearing a poorly developed soil, marks the disconformity between the Alpine and Bonneville formations.

At most places the Bonneville-Alpine boundary can be readily traced by these textural contrasts. Commonly there also is a pronounced topographic break in the high-shore zone, with the gravel of the Bonneville rising 35 to 50 feet above the Alpine formation, to the Bonneville shoreline.

Southwest of Santaquin are five prominent bars composed largely of gravel of the Bonneville formation disconformable upon the silt of the Alpine formation (pl. 5). They lie in a valley, 2 miles wide, where southern Utah Valley narrows between the southern Wasatch Mountains on the east and Long Ridge on the west. The bars average 1 mile long and 600 feet wide. Two extend about $1 \frac{1}{2}$ miles northward from the Juab-Utah County line. The other three are alined southwest-northeast across secs. 2, 3, 10, and 11, T. 10 S., R. $1 \mathrm{E}$, and.a small offshore bar parallels them in the center of sec. 11 . The areal pattern of all the bars, together with decreasing coarseness of gravel northward, indicates that northward-flowing longshore currents from Juab Valley were funneled through the narrow pass between Juab and Utah Valleys, then, as the valley widened to the north, the currents dropped their load in long linear bars as their competency and capacity decreased. Similar littoral bars were formed during Provo time by northward- and northwestwardflowing longshore currents (Hunt and others, 1953, p. 21-23).

\section{PROVO FORMATION}

Hunt (Hunt and others, 1953, p. 21) defined the Provo formation as including "the deposits that were laid down while Lake Bonneville stood at what Gilbert (1890, p. 126-134) called the Provo stage." In this report the Provo formation is defined as those sediments of Lake Bonneville that were deposited at and below the Provo shoreline and overlie the Alpine formation. It is the youngest formation of the Lake Bonneville group in southern Utah Valley. The Provo shoreline here is at an altitude of about 4,800 feet, about 335 feet below the Bonneville shoreline. (Gilbert (1890, p. 127) reported that over the whole area of Lake Bonneville, the Provo shoreline, generally, is 375 feet lower than the Bonneville shoreline. However, his determination of the average altitude of the Bonneville shoreline $(5,200 \mathrm{ft})$ seems to have been somewhat in error.)

The Provo formation is more widely exposed than the Alpine and Bonneville formations combined, and underlies most of the terrain between the Provo shoreline and Utah Lake. Its deltas, spits, bars, and beaches are among the most conspicuous topographic features in southern Utah Valley. The deltas are on the eastern side of the valley, built by streams from the Wasatch Mountains; most of the spits are on the western side. Bars are abundant on both sides.

The Provo formation is divided into gravel, sand, silt, and clay members, which are facies gradations of approximately contemporaneous age. In places gravel at the base is overlain in turn by sand, then silt, and finally clay. At other places one member grades laterally into one or more of the others.

Late in Provo time, after the lake had dropped at least as low as 4,700 feet, it again rose to about 4,770 feet, within about 30 feet of the former Provo stillstand. During the lake recession, loess, alluvium, and volcanic ash were locally deposited, and a submature soil was formed before deposition of the late Provo lake sediments. These late Provo sediments are of only local extent and thin, and are included with the rest of the the Provo formation on plate 5.

\section{GRAVEL MEMBER}

Gravel of the Provo formation occurs principally in deltas built at the mouths of the larger streams issuing from the Wasatch Mountains. It also occurs in bay bars, spits, bars in front of the deltas, linear bars in narrow valleys, in shore terraces and beaches between the deltas, and surrounding the mountain ridges within the valley. The maximum thickness of this member is about 125 feet. Commonly the larger features of Provo age, such as deltas and spits, are composite, being capped by gravel of the Provo formation and underlain by the Bonneville and Alpine formations. 
The delta of Provo age built principally by Spanish Fork is the largest delta in southern Utah Valley, having an area slightly greater than 35 square miles. It has a central facies of gravel that grades northward into sand and southwestward into silt, a relationship also noted on the deltas in northern Utah Valley (Hunt and others, 1953, p. 22). The gravel drift indicates northward-flowing currents along this part of the eastern shore of the lake, and the facies changes within the delta suggest the same. The sand was carried north beyond the gravel while silt accumulated in the shallower water on the southwestern side.

The composite delta of Provo age built by Hobble Creek, Spring Creek, and nearby smaller streams is not typically deltoid in plan, but is elongate to the northwest. Its shape, internal structure, and textural distribution also indicate strong northwestward-flowing littoral currents.

The beach and spit deposits are similar to those at the distal ends of the deltas. They contain many beds of medium to coarse gravel, a high percentage of fine gravel and sand, and some silt; they also have excellent sorting and well-developed bedding (fig. 31). The

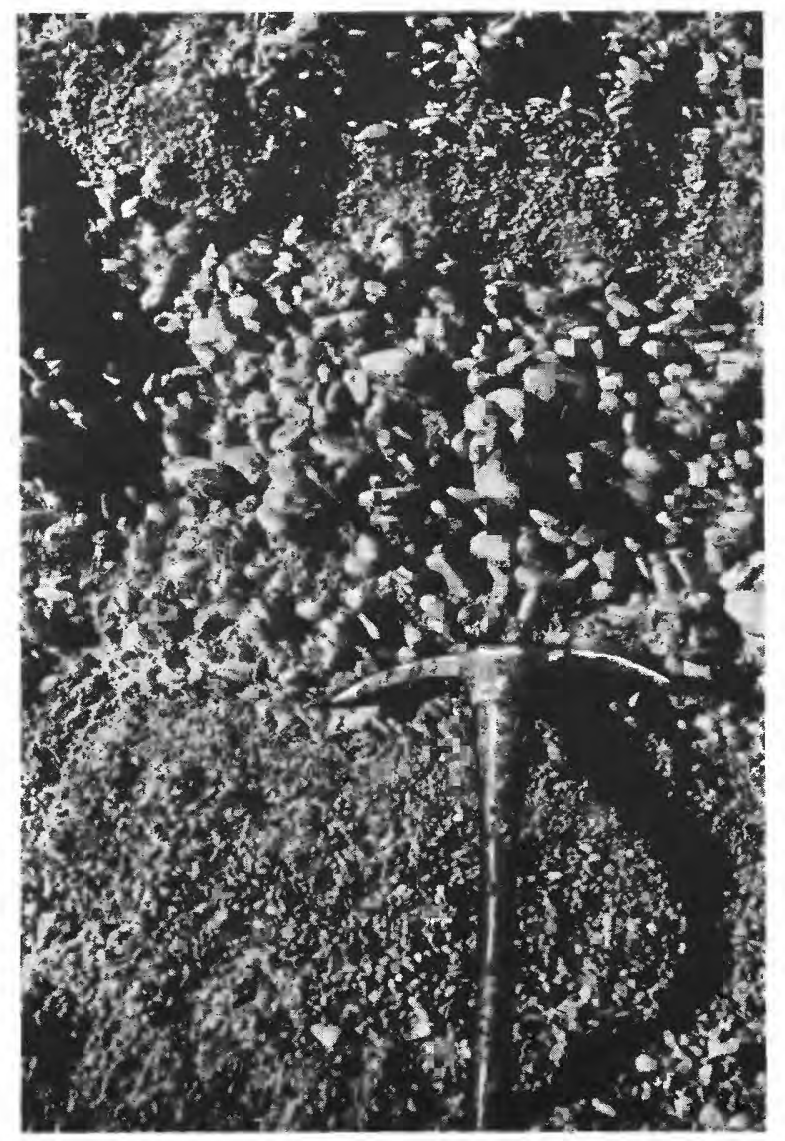

Figure 31.-Details of sorting in gravel of the Provo formation east of Springville. shore terrace deposits have the same general internal structure (figs. 32, 33) as the deltas, with basinwarddipping foreset beds and well-developed topset and bottomset beds. Gravel spilled over the outer edges of the terraces widening them and forming gravel embankments only a few feet thick on the wave-cut sides of the terraces, but commonly many tens of feet thick basinward. Commonly, sand is interbedded with the gravel, and contains mollusks.

At the northern end of Little Mountain is a spit of Provo age, on which the eastern part of Payson is built. Here the gravel of the Provo formation is boulder and cobble gravel with minor amounts of admixed sand and silt, overlying the Alpine and Bonneville formations. On the north and west sides of West Mountain are three well-defined spits of Provo

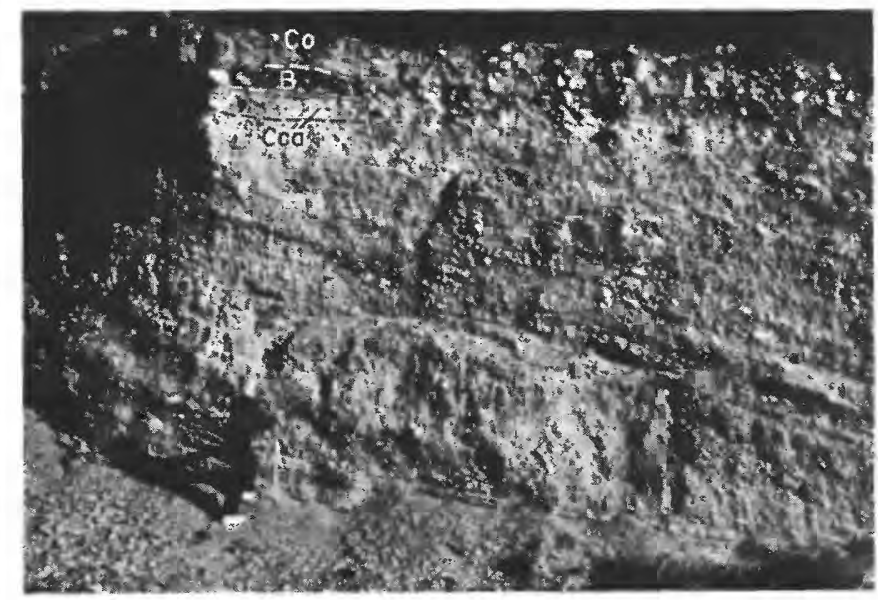

FIGURE 32-Submature post-Provo, pre-Utah Lake soil, developed on deltaic gravel of the Provo formation. $B$ indicates the $\mathrm{B}$ horizon of the soil; $C c a$, the Cea horizon; and $C o$, younger colluvium overlying the soil. Thorn gravel pits west of the mouth of Slate Canyon.

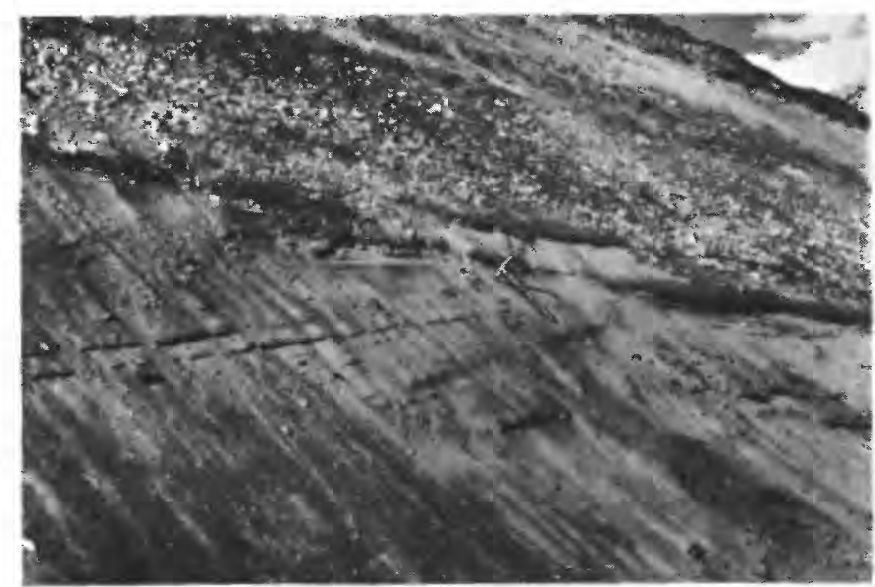

Figure 33-Delta deposit of the Provo formation showing topset beds of gravel truncating foreset beds of gravel and sand. Road-cut exposures, Brigham Young University campus, Provo. Pick is 18 inches long. 
age, over earlier spits of Alpine and Bonneville age. Their structure and textural distributions indicate currents of strong northward drift.

South of Salem a long bay bar of Provo age lies north of and somewhat lower than a larger parallel bay bar of gravel of the Alpine formation. Northwest of Santaquin, $1 / 2$ to 1 mile east of the junction of Long Ridge and West Mountain, is a prominent long narrow bar of Provo age.

Gravel of the Provo formation ranges widely in texture, structure, composition, and size-grade distribution. Sorting ranges from excellent to none; bedding is well developed to absent. Most of the gravel is coarse, and contain a large proportion of cobbles and boulders; but tongues and intercalations of sand and silt also are common.

The bar gravel commonly is shingled and locally imbricated lakeward; beds of open-work gravel and steep foreset bedding are common.

Pebble, cobble, and boulder counts in the gravel pits southwest of Spanish Fork indicate the following averages: quartzite and sandstone, 43 percent; limestone, 31 percent; and volcanic rocks (mainly andesite), 26 percent.

An excavation in the Payson spit, made for an electric railway but since filled in, showed mostly coarse boulders and cobbles in the eastern half, and sand, silt, and fine gravel in the western half. Beds in the eastern half also are much better stratified and sorted, and dip an average of $10^{\circ} \mathrm{E}$. Boulder, cobble, and pebble counts made in various beds in this half are as follows: Volcanic rocks (mainly andesite), 52 percent; quartzite and sandstone, 36 percent; and limestone, 12 percent. The volcanic material came from bedrock outcrops and pre-Lake Bonneville fan gravel in Payson Canyon. Mechanical analyses of the gravel member are given in table 10 and figure 34 .

Wells drilled for water in southern Utah Valley show that gravel of the Provo formation does not extend in the subsurface very far basinward, except locally in the deltas. West of Springville and Spanish Fork the subsurface basinward extension of gravel in the deltas averages 40 to 45 feet in thickness and between the two cities locally thickens to 85 feet. A 310 -foot well in the northern end of the Payson spit, in the $\mathrm{SW}^{1} \frac{1}{4}$ sec. 4 , T. 9 S., R. 2 E., penetrated about 45 feet of gravel assigned to the Provo formation. A 440-foot well east of this spit and near U.S. Highway 91, in the $\mathrm{SW}^{1 / 4}$ sec. 10, T. 9 S., R. 2 E., penetrated 47 feet of gravel in the Provo, but a well half a mile northeast of this one did not penetrate gravel in this formation. Tom Woodhouse, who drilled these wells, reported no gravel in any wells that he has drilled in the general vicinity of Salem, which suggests that the gravel member of the
Provo formation does not extend very far into the basin in this area.

Logs of wells in Goshen Valley indicate that the subsurface thickness of the gravel member there ranges from 40 to 60 feet.

\section{SAND MEMBER}

The sand member of the Provo formation represents five depositional environments: deltas, bars in front of deltas, bars unrelated to deltas, embankments on
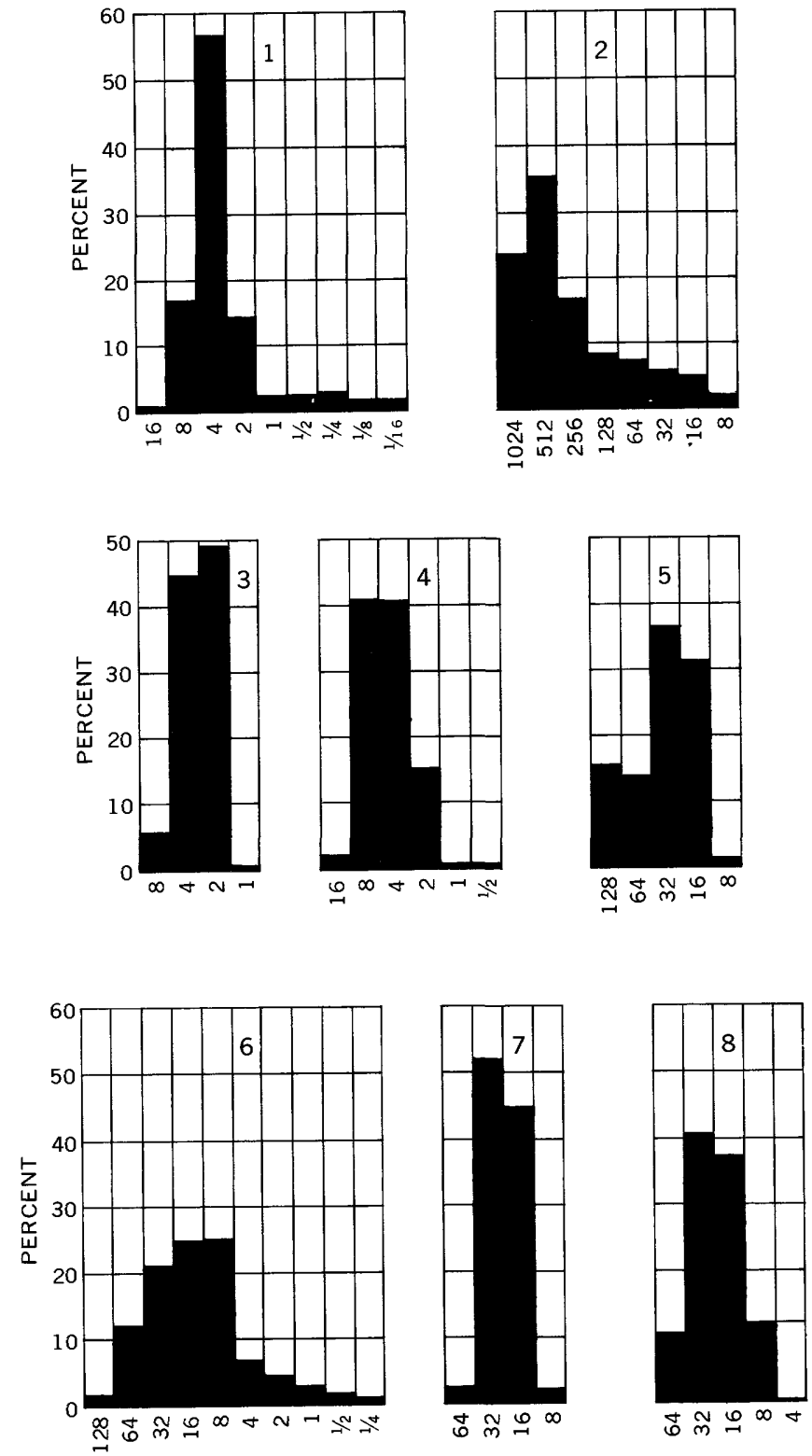

FIGURE 34-Bar graphs of mechanical analyses of the gravel member of the Provo formation. 1, Hobble Creek delta (SE1/4 sec. 34, T. 7 S., R. 3 E.). 2, Payson Canyon spit (SE1/4 sec. 9, T. 9 S., R. 2 E.). 3, Terrace deposit (SW1/4 sec. 20, T. 9 S., R. 2 E.). 4, Bar deposit, Salem (SW $1 / 4$ sec. 15, T. 9 S., R. 2 E.). 5, Beach deposit (SE1/4 sec. 33, T. 9 S., R. 1 E.), 6, Distal end of delta (NW1/4 sec. 25, T. 8 S., R. 2 E.). 7, Terrace deposit (SE1/4 sec. 17, T. 9 S., R. 2 E.). 8, West Mountain spit (NE1/4 sec. 7, T. 9 S., R. 1 E.) 
TABLE 10.-Mechanical analyses of the gravel member of the Provo formation [Sample numbers are not coordinate with those in figure 34. Percentage weights from screen analyses. Diameter, in millimeters]

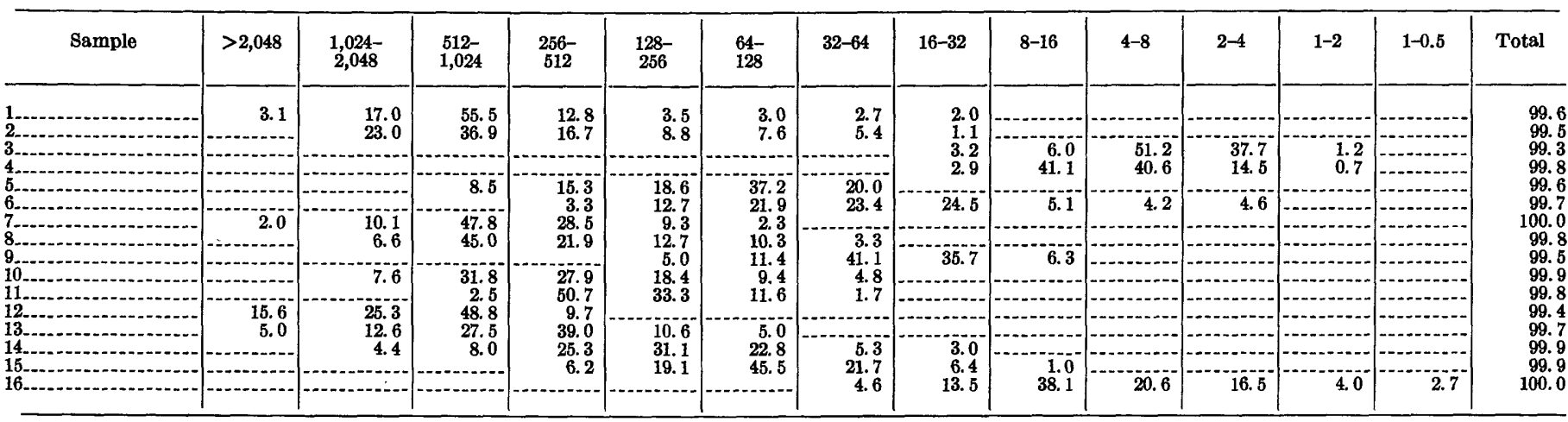

steep hillsides, and offshore bottom selvages transitional between the gravel; silt, and clay members. The sand member crops out extensively but commonly without prominent topographic expression, and good exposures are not abundant. In mapping, soil texture generally was an excellent guide where exposures were lacking, but in places was supplemented by augering and trenching.

The Spanish Fork delta, largest in southern Utah Valley, contains about 8 square miles of the sand member. The Goshen delta, though smaller, contains almost as much sand. The Springville delta contains little sand, except where it merges southward with the Spanish Fork delta. One small patch in the NE $1 / 4$ sec. 3, T. 8 S., R. 3 E., surrounded by gravel, probably was deposited on the subaerial part of the delta.

In front of the Spanish Fork delta are two sand bars; one northwest of Salem in the W $1 / 2$ sec. 35, T. $8 \mathrm{~S} .$, R. $2 \mathrm{E}$. is about 1 mile long and averages a quarter of a mile wide; the other is north of Spanish Fork in sec. 7 , T. 8 S., R. 3 E. and is slightly more than 1 mile long and averages slightly less than a quarter of a mile wide. Both bars are elongate northeastward and overlie finer grained sediments.

A large embayment at the mouth of Currant Creek south of Goshen contains an extensive deltaic deposit of the sand member, forming the most prominent Pleistocene landform here. The sand is predominantly light colored and composed of quartz and calcite grains most of them well abraded and some well rounded. Rare components are dolomite and minerals that are characteristic of latite. The nearest bedrock that crops out is on Long Ridge to the south and east and consists primarily of dolomite, magnesian limestone, limestone, and latite. Probably the quartz and calcite were derived from the Oquirrh and Tintic formations in the East Tintic Mountains and became mixed with other sediments brought from Juab Valley by Currant Creek.
Embankment deposits of the sand member are second only to the delta deposits in outcrop area. Most of the embankment deposits are in the western half of the valley. Southeast and southwest of Goshen delta deposits merge into embankment deposits.

A broad band of this sand extends eastward from Salem nearly to the Wasatch mountain front. This deposit is generally even textured, fine grained, and grades basinward into silt and clay. Southeastward it grades into beach gravel and sand. It is overlapped on the south and southeast by a gravel bar of the same formation. Little is known about the thickness of the sand member in this area, but logs of wells drilled for water penetrated 110 to 120 feet of very fine sand immediately north and west of Salem. According to Tom Woodhouse, wells drilled in and adjacent to Salem penetrated as much as 150 feet of sand. Profiles and well-log data on the sand member indicate that it dips basinward about $5^{\circ}$ near Salem.

In the west half of southern Utah Valley the sand member crops out in four belts: west of Santaquin near the east side of the junction of Long Ridge and West Mountain; in the shallow reentrant on the west side of this junction; in the broad embayment southeast, south, and southwest of Elberta; and northwest of Elberta in a very broad area valleyward from the East Tintic Mountains. A small deposit lies on the west side of West Mountain near its base. None of these deposits is topographically prominent.

The delta sand deposits southwest of Spanish Fork, exposed in gravel and sand pits, are well stratified, medium to fine grained, and excellently sorted. They invariably contain tongues and lenses of poorly sorted subangular to subrounded cobbles and pebbles. Near the distal end of the delta are cobbles as much as 8 inches in diameter mixed with fine sand, silt, and locally clay. The cobbles and pebbles are largely latite, andesite, quartzite, sandstone, and limestone. The nearest source of the sedimentary rocks is $3 \frac{1}{2}$ miles southeast of Salem; the source of the latite and 
andesite is near Little Mountain south of Payson, about 5 miles southwest. Much of the material in this end of the Spanish Fork delta was derived from the hard rocks and pre-Lake Bonneville fan gravel south of Payson and Salem. Spanish Fork transported most of the material that forms the delta, but much sediment was added from longshore drift, moving north and northeast from the Payson-Salem region.

Mechanical analyses of representative samples of the sand member are given in table 11 .

TABLE 11.-Mechanical analyses of the sand member of the Provo formation

[Percentage weights from screen analyses. Diameter, in millimeters]

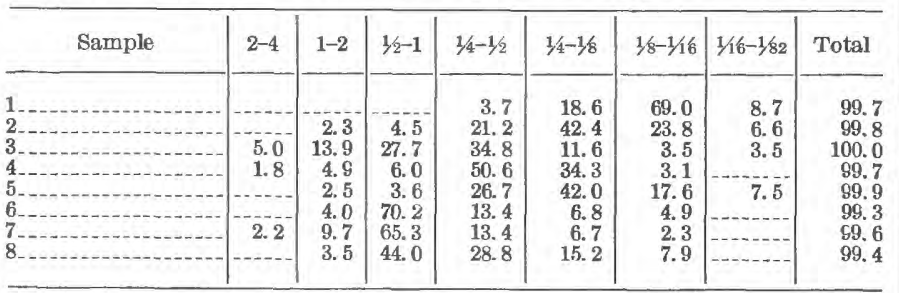

1. Delta southeast of Springville (east-central 1/4 sec. 3, T. 8 S., R. 3 E.)

Bar in front of the delta north of Spanish Fork (center of sec. 7, T. $8 \mathrm{~S} .$, R, $3 \mathrm{E}$.) Spit east of Payson (in SE1/4 sec. 9, T. 9 S., R. 2 E.)

distal end of Spanish Fork delta, South of Spanish Fork (in SE1/4 sec. 25, T. 8 S., R. 2 E.)

5. Terrace deposit southwest of Goshen (in the SE1/4 sec. 23, T. 10 S., R. 1 W.)

7. South margin of the Spanish Fork delta, (in the NE1/4 sec. 32 , T. 9 S., R. 1 W.

S., R, 3 E )

8. Terrace near Payson (in the SW1/4 sec. 17, T. 9 S., R. 2 E.)

\section{SILT MEMBER}

The silt member of the Provo formation forms a part of each of the deltas, but the principal deposits are transitional selvages between gravel and sand of the shore zone and the clay of the lake bottom. The silt, commonly about 25 to 30 feet thick in exposures, is light gray, rather homogeneous in texture, and is less well stratified than silt of the Alpine formation. It generally is difficult to recognize this member in well logs because drillers usually group the silt either with clay or fine sand. However, in the subsurface the silt probably ranges from 15 to 35 feet thick west of the steel plant at Ironton, in the Springville-Spanish Fork area, and elsewhere in the western half of southern Utah Valley.

The largest outcrop is northwest, west, and southwest of Spanish Fork. This silt also is exposed in a broad belt extending from the east and north outskirts of Salem westward as far as the Payson spit, and it mantles foreset beds on the Hobble Creek-Spanish Fork delta. It is also exposed in a broad belt between Payson and Santaquin, locally near Genola Church and Goshen, and west of Goshen Valley and Utah Lake. Some of the finest exposures, showing internal structure, composition, and texture, are in a gully about 1 mile west of Mapleton (fig. 35 ) in sec. 9, T. 8 S., R. 3 E.
The silt member in western Goshen Valley, north of Goshen and Elberta and along the western side of Utah Lake, contains much very light gray to chalk-white diatomaceous silt, marly diatomite, and diatomite. These beds are commonly 6 to 8 feet in total thickness, locally as much as $\mathbf{1 0}$ feet thick, and are mapped as a separate unit within the silt member. They crop out mainly in a narrow belt north and south of Elberta, being well exposed by many prospect pits. One of the best exposures is $3 \frac{3 / 4}{4}$ miles north of Elberta, about 100 yards west of the Elberta-Mosida road. The diatomaceous unit is high in acid-soluble material; samples digested in cold $N / 100 \mathrm{HCl}$ had 47 to 65 percent soluble carbonate. Some of the soluble material is fine-grained calcium carbonate; however, a 2- to 3 -foot zone of marly silt rich in tests of the mollusks Fluminicola fusca (Haldeman), Lymnaea utahensis Call, and Valvata utahensis Call accounts for much of the soluble material. Downward leaching and redeposition from higher beds also has added much carbonate to the diatomaceous unit.

The restricted, linear occurrence of the diatomaceous unit is puzzling. Diatoms have not been found elsewhere in the Lake Bonneville group in southern Utah Valley. Perhaps the diatoms flourished because of silica-bearing spring water in this area.

Diatomaceous beds that may be equivalent to the diatomaceous unit in Goshen Valley are exposed in a gravel pit southeast of Payson, in the south-central part of sec. 15, T. 9 S., R. 2 E. (fig. 36). They occur in unit 4 in the following section.

Stratigraphic section of Provo formation, exposed in a gravel pit southeast of Payson. Top of section about 4,750 ft alt.

1. Silt, grading laterally to fine gravel, darkbrown to black (bears post-Lake Bonneville soil) _... $0.9-1.5$

2. Gravel with silty brown matrix at top (lower part of post-Lake Bonneville

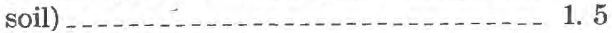

3. Pebble gravel and granule (pea) gravel, moderately well sorted, strongly lime cemented (lake tufa and possibly some soil lime or secondary lime) _......... 5.0

4. Diatomaceous to bentonitic silt and volcanic ash, white to yellow-white. Partial remains of a Pleistocene elephant, Elephas sp., excavated from lower part of this bed ........................

5. Small cobble gravel and pebble gravel, mostly unsorted................ 1.5

6. Very fine sand, well-sorted, with lenses of cobble and pebble gravel. Base not reached.......................... 0

$13-15.5$ 


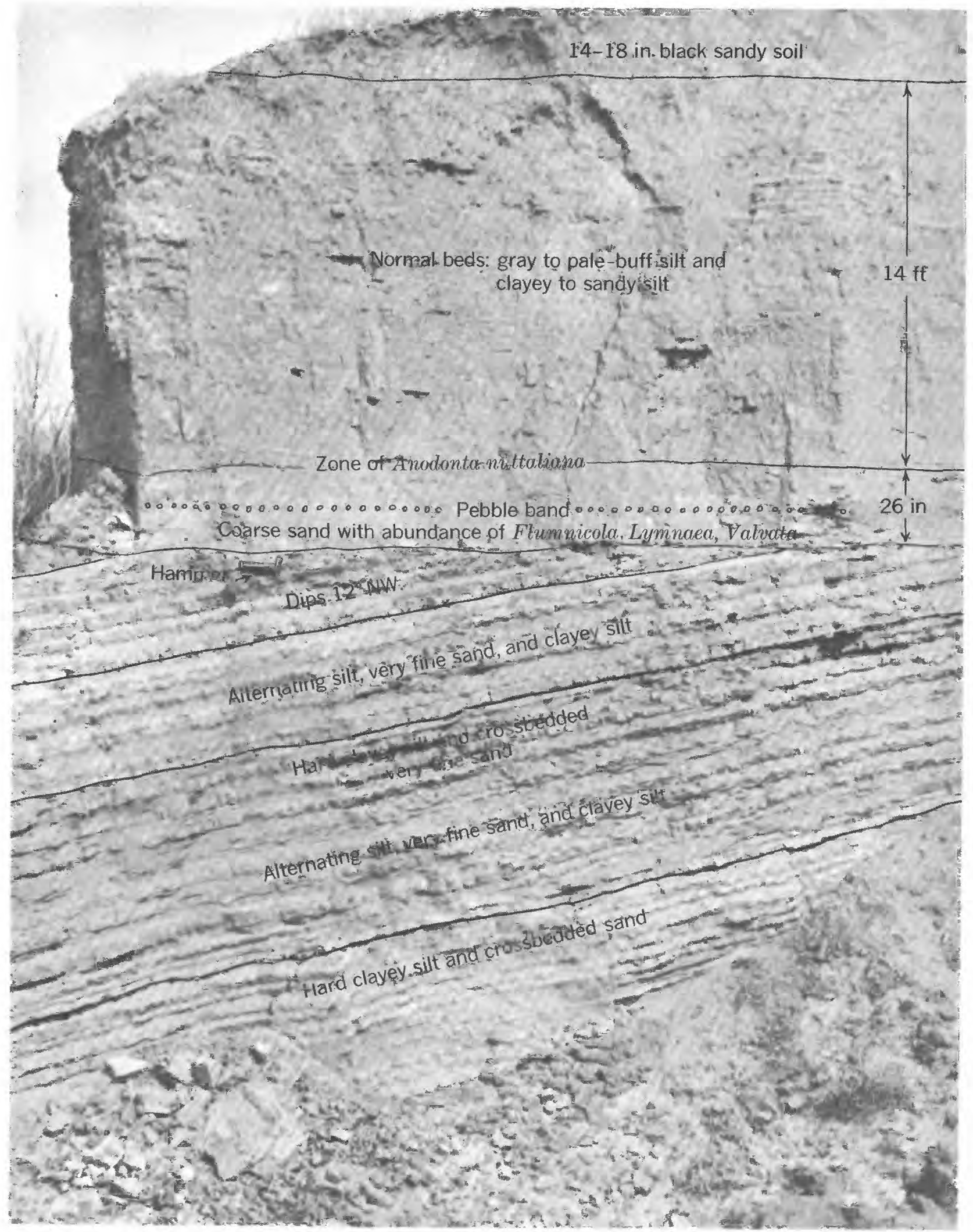

FIGURE 35.-Deltaic silt and fine sand in the silt member of the Provo formation in a gully about 1 mile west of Mapleton. 


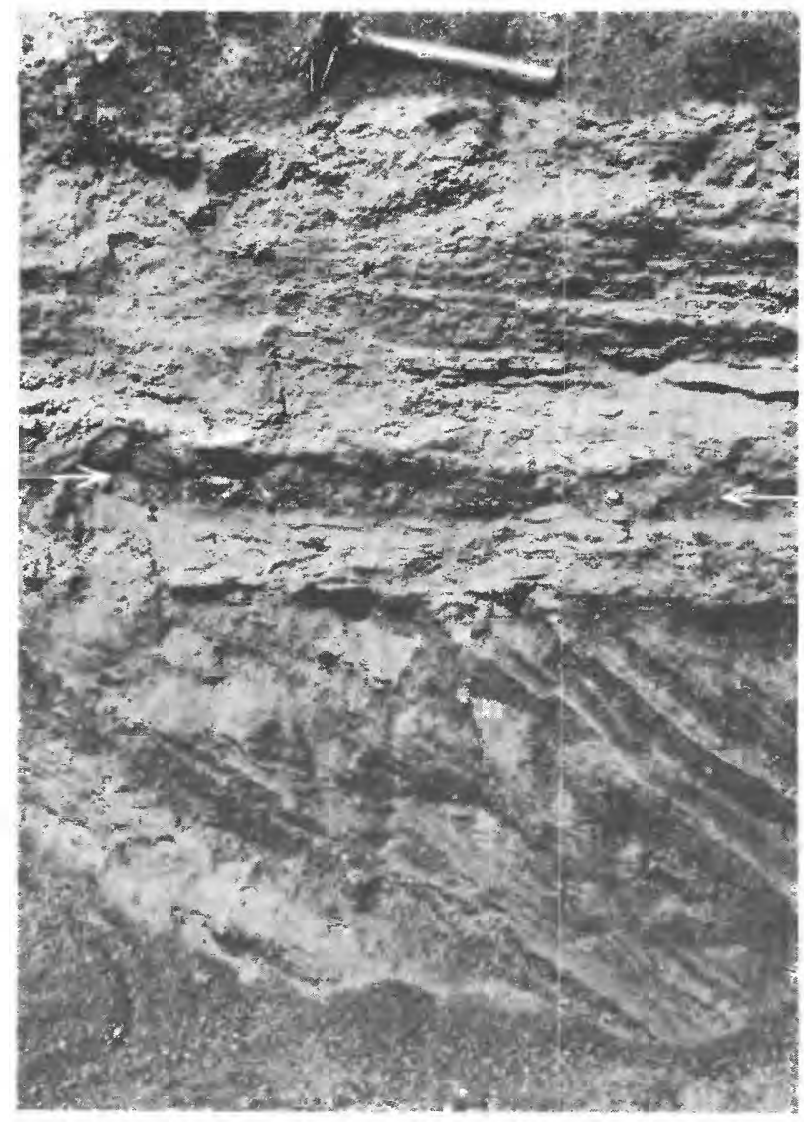

Figure 36.-Foreset beds of an embankment deposit of gravel of the Provo formation, southeast of Payson, overlain by the diatomaceous unit of the silt member. Arrows indicate base of silt member.

Mechanical analyses of representative samples of the silt member are shown in table 12 .

TABLE 12-Mechanical analyses of the silt member of the Provo formation

[Percentage weights from screen analyses. Diameters, in millimeters]

\begin{tabular}{|c|c|c|c|c|c|c|c|c|c|}
\hline Sample & $1 / 4-1 / 2$ & $1 / 4-1 / 8$ & $1 / 8-1 / 16$ & $1 / 16-1 / 32$ & $1 / 32-1 / 64$ & $1 / 64-1 / 128$ & $1 / 128-1 / 256$ & $1 / 256-1 / 512$ & Total \\
\hline $\begin{array}{l}5 \\
6 \\
7 \\
8\end{array}$ & \begin{tabular}{c}
-1.5 \\
\hdashline
\end{tabular} & $\begin{array}{r}3.0 \\
4.9 \\
-\end{array}$ & $\begin{array}{r}25.7 \\
3.4 \\
1.4 \\
3.2 \\
9.7 \\
7.6 \\
3.3 \\
5.2\end{array}$ & $\begin{array}{r}47.8 \\
20.3 \\
4.4 \\
8.7 \\
11.1 \\
17.1 \\
14.9 \\
23.1\end{array}$ & $\begin{array}{r}9.1 \\
65.0 \\
12.5 \\
25.4 \\
54.6 \\
60.3 \\
67.8 \\
55.8\end{array}$ & $\begin{array}{r}5.5 \\
4.7 \\
48.6 \\
42.9 \\
15.5 \\
6.5 \\
11.5 \\
13.7\end{array}$ & $\begin{array}{r}0.8 \\
2.3 \\
23.4 \\
17.7 \\
5.4 \\
2.0 \\
1.8 \\
2.0\end{array}$ & $\begin{array}{r}9.6 \\
3.8 \\
.7 \\
.5 \\
.5\end{array}$ & $\begin{array}{r}99.8 \\
99.5 \\
99.9 \\
99.8 \\
100.0 \\
99.9 \\
99.8 \\
99.8\end{array}$ \\
\hline
\end{tabular}

CLAY MEMBER

The clay member of the Provo formation crops out broadly in the lower parts of Utah Valley. It was deposited as aprons in front of the deltas and on the lake bottom.

The five principal outcrop areas are (1) around Provo Bay (of Utah Lake) and southward to Springville; (2) south of Springville extending to Spanish Fork, an area known locally as the clay beds because of the characteristic clayey soil; (3) a broad strip west from Payson almost to West Mountain; (4) encircling Goshen Bay of Utah Lake; and (5) a belt, 2 miles wide, extending southward in the Goshen area.

The clay is uncommonly thick and extensive in front of the Spanish Fork delta, and it commonly mantles part of the delta front. This probably reflects extensive exposures of shale of the Green River formation of Eocene age in the drainage basin of Spanish Fork River.

These deposits are similar in texture, composition, color, mode of occurrence, and habit of weathering. When dry, the clay is hard and firm, and bakes under the sun to a light-gray and chalk-white claystone, but when wet, it is gray, plastic and sticky. About 14 to 18 inches above the perennially saturated part below the water table is a zone, subject to alternate wetting and drying, that is brick red, presumably due to concentration of hydrous iron and aluminum oxides.

The clay member is poorly drained, and in the dry season a crust of white "alkali" commonly forms where rising ground water leaches the salts from the clay and deposits them on the surface of the ground as an efflorescence.

EVIDENCE OF INTRA-PROVO LAKE RECESSION AND LATE PROVO LAKE MAXIMUM

Locally a disconformity representing subaerial erosion, a submature soil, and a few inches to several feet of eolian silt and sand separate the uppermost part of the Provo formation from the main part. The subaerial features have been found as low as altitudes of about 4,720 feet, indicating intra-Provo lake recession at least this low, and the overlying lake sediments of the upper part of the Provo formation reach an altitude of 4,760 feet, the maximum of a minor late Provo lake cycle. Three localities that record the lake recession and readvance are as follows:

1. A gravel pit southeast of Payson, where the strati graphic section given on page 117 was obtained. Likely the elephant, whose remains were found in unit 4, became trapped in these sediments during the brief recession. The overlying gravel and silt was deposited during the subsequent readvance.

2. A gully just east of U.S. Highway 91 about 1 mile south of Payson and in the central part of sec. 20, T. 9 S., R. 2 E., at an altitude of 4,720 feet, exposes silt and fine sand overlain by remnants of slightly weathered loess, overlain, in turn, by lake gravel, sand, and silt. Apparently the lake dropped at least 80 feet from its highest level in Provo time, the loess was deposited and slightly weathered, and then the lake rose, depositing the upper gravel, sand, and silt.

3. Gravel pits south of Elberta in secs. 17 and 20, T. 10 S., R. 1 W., also show eolian silt and sand un- 
conformably above the diatomaceous unit of the silt member and overlain by younger gravel of the Provo formation. In the north-central part of sec. 32 and the south-central part of sec. 29 , T. 9 S., R. 1 W., the diatomaceous unit is unconformably overlain by windblown sand, overlain in turn, by lacustrine silt.

\section{FOSSILS}

Mollusk shells are common in the silt member and occur locally in the sand member, especially where a gravel lens grades upward into sand, or at a sharp contact of gravel and sand or sand and silt, or, rarely, clay and sand. In the gravel member, mollusk shells occur in sand, silt, or clay lenses. The following species have been collected; those which are conspecific with types collected by Hunt, Varnes, and Thomas (1953, p. 24) in northern Utah Valley are shown by an asterisk:

\section{* Amnicola lingingua Gould \\ Anodonta nuttalliana Lea \\ Carinifex newberryi (Lea) \\ * Fluminicola fusca (Haldeman) \\ * Lymnaea utahensis Call \\ Physa lordi Baird ef. P. ampullacea Gould \\ Pisidium sp. \\ Pompholopsis, cf. P. whitei Call \\ Sphaerium pilsbryanum Sterki \\ Valvata utahensis Call}

All these species have also been collected from sediments of Utah Lake; the similar or identical fauna suggests that the environmental conditions of Provo time have continued with little change into the Recent. The habitat of these species is a shore marsh rich in organic material, such as prevails around present-day Utah Lake.

Collections of ostracodes from the silt member were submitted to F. M. Swain, of the Department of Geology, University of Minnesota, who reported as follows:

Ostracodes from the Provo formation:

Candona sp. aff. C. candida (Müller) _. ........ Common

This species is Holarctic in its distribution and is found in Europe and North America. It occurs in almost every freshwater environment and in some of the brackish, tidal areas of England and Europe. It prefers still water to running water.

Candona ef. C. lactea Baird Common

Limnicythere ef. L. sancti-patricii Brady and Robertson . . . . Common

Limnicythere n. sp. aff. Cytheridea

lacustris (G.O. Sars) ................ Abundant

Limnicythere cf. L. inopinata (Baird) Common

These species are Holarctic and typically are fresh-water lacustrine, but Limnicythere inopinata has also been obtained from brackish tidal waters. Its presence might suggest that, seasonally, Provo Lake became slightly saline at this level, but as the species also occurs in fresh water, such evidence is not conclusive. "Cytheridea" lacustris (Sars) probably closer to
Limnicythere, to which one of the forms from this locality is related, occurs both in fresh and brackish water. As Candona lactea seems to have been taken more often from rivers, its presence here may indicate that it was washed into Provo Lake by streams.

Ostracode collections made on the west side of Utah Lake from the silt member also were reported by Swain as follows:

Candona cf. C. candida (Müller) _..... Abundant
Candona ef. C. lactea (Baird)
Cypridopsis sp -
Limnicythere sp. aff. L. inopinata (Baird) - Rare
Limnicythere n. sp. aff. Cytheridea lacus-
$\quad$ tris (Sars)

Cytheridea cf. C. torosa (Jones) _....... Very abundant

The faunule is Holarctic. Candona lactea may have been washed in by streams. Cytheridea torosa has been taken in fresh water, but seems to be found more typically in a brackish to nearly normally saline environment. Its presence in such abundance suggests that the prevailing environment was more or less saline. Seasonal changes might account for the presence of the other more typically fresh water forms. Hoff $(* * * 1942$, p. 33) says that many of the modern nonmarine forms are seasonal, the eggs deposited in one season remaining attached to 'some substratum', usually plants, until the next favorable season.

Thus, water in Lake Bonneville was probably moderately saline while the silt member accumulated. Southern Utah Valley at that time received much saline material by way of Currant Creek, which drains from Juab Valley.

Samples of the diatomaceous unit of the silt member were collected in the field with K. E. Lohman, U.S. Geological Survey. He studied the diatoms and reports as follows:

Identification of 73 species and varieties of diatoms in the first of the suite of 16 samples from the silt member of the Provo formation of Goshen Valley, Utah, has been completed.

A report on the first sample (U.S.G.S. diatom locality 3304, Bissell Collection No. 311(a)) follows. This is from the silt member, Provo formation, Lake Bonneville group, sec. 29, T. 9 S., R. 1 W., Goshen Valley east of Tintic Range, Utah County, Utah, 5 feet 10 inches below top. Collection was made 8-17-49.

The following species and varieties of diatoms have been identified and the frequency of occurrence indicated by $\mathrm{R}=$ rare; $\mathrm{F}=$ frequent; $\mathrm{C}=$ common; and $\mathrm{A}=$ abundant.

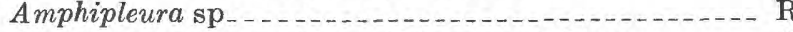

Amphora ovalis var. libyca (Ehrenberg) Cleve........ C proteus Gregory

Anomoconeis polygramma (Ehrenberg) Cleve......... $\mathrm{R}$ sp . .

Caloneis amphisbaena (Bory) Cleve _.............. R schumanniana (Grunow) Cleve.............. R silicula (Ehrenberg) Cleve_................. R

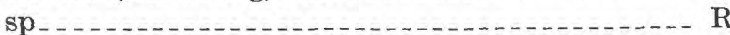

Cocconeis disculus Schumann _.................. C aff. C. grovei Schmidt_....................... R

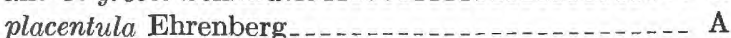

Cyclotella antiqua Wm. Smith_..._._._. Kutzingiana var. planetophora Fricke............... C

Cymatopleura elliptica (Brebisson) Wm. Smith........ R solea (Brebisson) Wm. Smith _................. R 
Cymbella cistula (Hemprich) Grunow ............ A

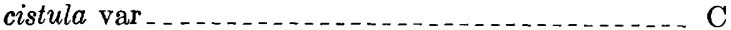
ef. C. ehrenbergii Kützing ................ R mexicana (Ehrenberg) Schmidt . . . . . . . . . . A mexicana var............ F obtusiuscula (Kützing) Grunow . . . . . . . . . . R R parva (Wm. Smith) Cleve................... C

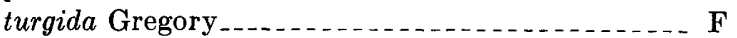

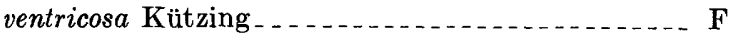

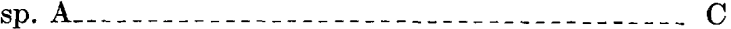
sp. B ........... F

Diploneis ovalis (Hilse) Cleve................. R smithii (Brebisson) Cleve................... $\mathbf{R}$

Epithemia argus (Ehrenberg) Kützing _............ A

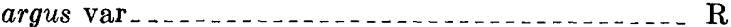
sorex Kützing . . . . . . . . . . . . . . . . . . . F turgida (Ehrenberg) Kützing . ............... C zebra (Ehrenberg) Kützing . . . . . . . . . . . . C zebra var. . . . . . . . zebra var. porcellus (Kützing) Grunow . . . ...... C zebra var. saxonica (Kützing) _................ C sp . . . . . .

Fragilaria brevistriata Grunow ................. C aff. F. mormonorum (Grunow) Boyer........... R construens var. binodis (Ehr.) Grunow .......... F harrissonii Wm. Smith . . . . . . . . . . .

Gyrosigma parkeri (Harrison) Boyer............... R Hantzschia amphioxys var. uticensis Grunow _....... F

Mastogloia elliptica Agardh................... C smithii var. lacustris Grunow.............. C

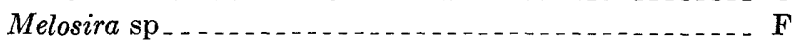

Navicula anglica Ralfe ........................ R oblonga Kützing . . . . . . . . . . F popula var. capitata Hustedt............... R radiosa Kützing . . . . . . . . . . . . . . . . reinhardtii Grunow ........................... $\mathrm{R}$ tuscula (Ehrenberg) Van Heurck ............ R viridula Kützing ............................ sp. A sp. B $B_{\ldots} \ldots \ldots$ sp. C

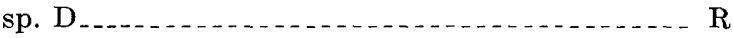

Neidium distincte-punctatum Hustedt . . . . . . . . . $\mathrm{R}$

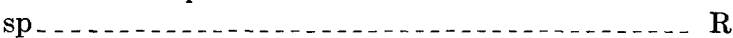

Nitzschia signoidea (Ehrenberg) Wm. Smith ......... F cf. $N$. tryblionella $\ldots \ldots \ldots$

Pinnularia microstauron (Ehrenberg) Cleve . . . . . . . . F viridis Nitzsch...............................

Rhoicosphenia curvata (Kützing) Grunow _........... C

Rhopalodia gibba (Kützing) O. Müller . . . . . . . . . C

Stavroneis cf. S. perpusilla Grunow _............. R

Surirella crumena Brebisson ................... F

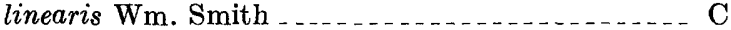

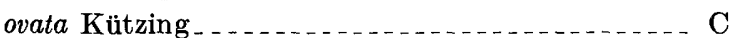

testudo Ehrenberg......................... R

utahensis Grunow .............................

sp

Synedra pulchella Kützing ....................... C

This diatom flora is a mixture of fresh-water and saline species, all of which are nonmarine, although some of the saline species inhabit brackish estuaries. All of the named species are represented in living assemblages; those indicated by "sp." or "sp. A," etc., are new, and hence known only from the present occurrence in the Provo formation of Pleistocene age. Inasmuch as many of the fresh-water species in this assemblage could not have lived in a saline lake (required by the saline species) it seems reasonable to suppose that they were carried into the lake by fresh-water streams. The salinity of the lake must have been high, as four of the most abundant species are living today in Pyramid Lake, Nev., which has a salinity of 3,486 parts per million, about $1 / 10$ that of sea water. The samples were all highly calcareous.

\section{FAN GRAVEL OF LAKE BONNEVILLE AGE}

South of Salem is an alluvial fan of early Lake Bonneville age. It is incised into, and is less dissected than, a large pre-Lake Bonneville fan; the younger fan is graded approximately to the Bonneville shoreline. The fan gravel resembles the local pre-Lake Bonneville fan gravel, but it bears only the middleLake Bonneville soil (pl. 5).

Santaquin is on an alluvial fan that is graded to the Provo shoreline and composed mostly of fan gravel of Provo age, locally with a veneer of younger fan gravel. The fan gravel of Provo age bears only the post-Provo, pre-Utah Lake soil (pl. 5).

\section{YOUNGER DEPOSITS \\ POST-PROVO EOLIAN SAND AND SILT}

In many places a few inches to locally a few feet of windblown sand and silt overlie the Provo formation notably on sandy and silty parts of deltas and other embankments. These deposits are mostly too small to be mapped. True dunes are rare; a few occur west of Provo near Provo River, others south of Goshen on the upper surface of the delta of Provo age, and others northwest of Elberta. The eolian silt and sand is dark brown and texturally rather homogeneous, although commonly it contains some pebbles (possibly admixed slope wash). Locally, the sand and silt have been deflated, leaving a lag gravel veneer.

\section{LATE AND POST-PROVO, PRE-JTAH LAKE FAN GRAVEI}

In Utah Valley, Lake Bonneville ended when the Provo Lake receded to an altitude of about 4,500 feet. The lake recession is recorded by offlap sediments forming bars and embankments and by wave-cut cliffs and benches. During the recession the streams from the mountains eroded gorges through the deltas and embankments of the Lake Bonneville group. The eroded material was deposited in large fans in front of the deltas, resting on the Provo formation. Provo, Springville, Spanish Fork, Payson, and Santaquin are on these alluvial fans. The fan that formed where Hobble Creek issues from Mapleton Bench, on which Springville is situated, is about 40 feet in maximum thickness in its central part and thins rapidly toward its edges.

The late and post-Provo, pre-Utah Lake fan gravel consists of boulder, cobble, and pebble gravel, characterized by poor sorting and lenticular bedding. 
Size grades range from clay to medium boulders, with small cobbles predominating commonly in a coarse sand matrix. The round stones are curvilinear to rounded. Unlike the lake-deposited gravel, only small amounts of calcium carbonate have accumulated in the surface layers. Where this alluvium rests on gravel of the Provo, it generally can readily be distinguished by its poorer sorting and stratification.

In the Salt Lake basin Gilbert (1890, p. 134-135) applied the name "Stansbury shoreline" to a postProvo stillstand of Lake Bonneville at an altitude of about 4,500 feet. The Stansbury level has not been recognized in Utah Valley, for it is about at the level of Utah Lake.

\section{DEPOSITS OF UTAH LAKE}

Hunt (Hunt and others, 1953, p. 29) states that "In the bottom of Utah lake is sediment that spans all the time that has elapsed since the Provo formation was deposited." In his geologic map (1953, pl. 1) he assigned to the Provo formation nearly all the sediment surrounding Utah Lake to the edge of the water, although he recognized there were thin younger deposits on top of the Provo (Hunt and others, 1953, p. 28, 29). In the present report the sediments deposited by Utah Lake of Recent(?) age are mapped separately.

The deposits of Utah Lake are mostly clay and silt but gravel and sand occur locally. The deposits are divided into five mappable units: gravel, sand, silt, clay, and tufa. They are mainly derived from the Provo formation, which they commonly resemble. Their aggregate thickness apparently does not exceed 50 feet, and the clay unit is thickest. They reach a maximum altitude of about 4,565 feet, about 78 feet above the present controlled level of Utah Lake, indicating a previously higher stand of Utah Lake than in modern times.

The gravel unit crops out in a narrow discontinous belt along West Mountain, at or very near the edge of Utah Lake, where it is part of the beach deposits. West of West Mountain, the gravel also forms part of a triangular bar in sec. 31 , T. 8 S., R. 1 E., and part of a spit in secs. 7 and 17, T. 9 S., R. 1 E.; east of Lake Mountains it forms thin beach and spit deposits.

The gravel, where reworked along the present lakeshore, commonly is shingled, especially beneath wavecut cliffs. Elsewhere it is heaped up in beaches and beach ridges 3 to 8 feet thick. The boulders, cobbles, and pebbles are mostly well abraded, roughly disc shape, and are derived from outcrops of sandstone, orthoquartzite, and limestone of the Oquirrh formation in West and Lake Mountains.

The sand unit crops out in both the eastern and western parts of southern Utah Valley. A beach deposit
$1 / 8$ to $1 / 4$ mile wide extends from near the mouth of Provo River southward along the edge of the lake to the channel connecting Provo Bay with the lake. From there the deposit ares southwest to the mouth of Spanish Fork and hence west as a high beach ridge a quarter of a mile wide almost to Lincoln Beach. Another broad beach with prominent beach ridges occupies a large irregularly shaped area a mile south of Provo on the northeast side of Provo Bay. This sand also occurs in a discontinuous deposit west of West Mountain near the lakeshore (secs. 9, 17, 20, and 29, T. 8 S., R. 1 E.), in a bar, spit, and small beach deposit northwest and west of Goshen Bay, in an offshore bar in secs. 15,22 , and 23 , T. 8 S., R. 1 W., in an almost continuous beach deposit north from near Mosida to Pelican Point, and in beach ridges a mile southeast of Mosida (secs. 6 and 15, T. 8 S., R. 1 W.).

The silt unit extensively underlies the bottom land and comprises much of the farming area of the Valley. It crops out in a broad expanse south of Provo, and in a narrow belt extending north from Mosida to near Pelican Point and south to a point west of Goshen Bay. It also crops out in a discontinuous belt west and northwest of West Mountain.

The clay unit almost completely borders the present edge of Utah Lake and also underlies most of the present lake bottom (Bissell, 1942, p. 62-69). The clay is dark gray, dark blue gray, and locally black owing to organic matter. It is typical of clay in a shallow marshbordered lake and is darker and richer in organic matter than the clay of Lake Bonneville.

The upper 5 to 8 feet of sediments on the bottom of Utah Lake is light-to-medium-gray silty clay that is fairly well sorted, poorly compacted, and contains 50 to 60 percent water. This bed grades downward into more compact medium to dark-gray clay, which extends to a depth of 15 feet. The more compact clay is poorly sorted and contains 40 to 50 percent water. Below this is a 10-foot bed of well-sorted dark-gray to black compact silty clay containing 33 to 43 percent water; it becomes sandy at a depth of about 25 feet.

The tufa unit (fig. 37) crops out in a small area north of West Mountain near Lincoln Beach and along a small strip of shore directly west. It also comprises most or all of Rock Island, although this island has a pedestal of quartzite according to W. P. Cottam. ${ }^{1}$ Although the outcrop area is small, soundings and core sampling indicate fairly large areas of tufa benęath the lake, now covered by water or clay. Waves breaking against the projecting headland at the north end of West Mountain have deposited tufa which is chalk white to light gray (medium gray when wet),

1 Cottam, W. P., 1926, An ecological study of the flora of Utah Lake, Utah: unpublished $\mathrm{Ph}$ D. dissertation, Ogden Graduate School of Science, Univ. Chicago. 


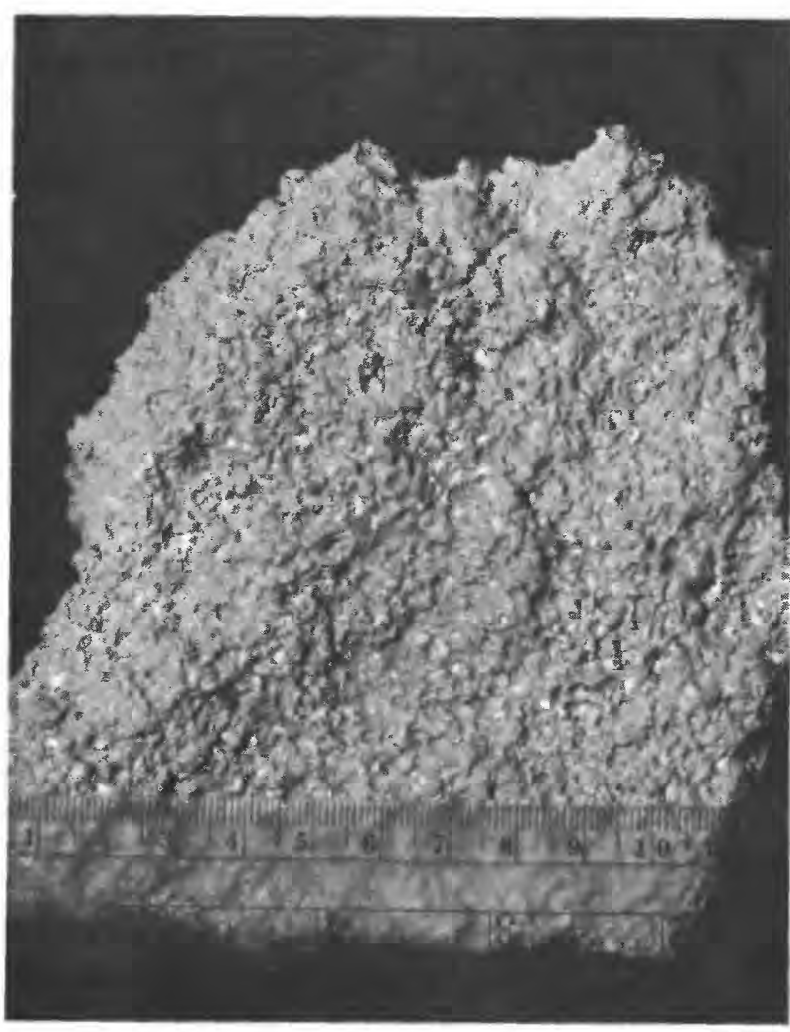

Frgure 37.-Tufa in Utah Lake deposits enclosing mollusk shells. Shore of Utah Lake at Lincoln Beach.

and spongy to compact. Algae may also be instrumental in precipitating the tufa. Locally, the tufa contains shells of the mollusk Fluminicola fusca (Haldeman). Locally elsewhere on the lakeshore, thin white coatings of tufa have formed on gravel deposits of Utah Lake.

\section{ALLUVIUM OF UTAH LAKE AGE}

Alluvium of Utah Lake age occurs along the present streams, both on small fans and on the flood plains, and locally intertongues with the deposits of Utah Lake. It is mainly gravel and sand, with some silt and clay, generally poorly sorted and lenticularly bedded. The fan gravel can be subdivided into older and younger deposits: the older gravel forms fans that are distinctly larger and slightly older than the younger fans. The older fans are locally coalesced into fairly extensive piedmont plains.

COMPARISON OF FAUNA OF UTAH LAKE AND LAKE BONNEVILIE AGES

All the mollusks collected from the Provo formation have also been found in the deposits of Utah Lake, including those of present-day Utah Lake. The following species, identified by Teng-Chien Yen, of the U.S. National Museum, have been collected from deposits of post-Provo age but have not been found in older deposits:
Lymnaea stagnalis jugularis Say

Helisoma trivolvis binneyi (Tryon)

Oreohelix strigosa depressa

Physa sayi Tappan

The following generalizations can be made about the occurrence of mollusks in the Lake Bonneville group and deposits of Utah Lake.

Gastropods are the most abundant mollusks in terms of genera, species, and individuals; they are wholly dextral in the Alpine and Bonneville formations; but both dextral and sinistral forms occur in the Provo formation and deposits of Utah Lake.

The following genera have not been found in the Alpine formation, but they were found in the Provo: Anodonta, Spherium, Helisoma, and Physa. As pointed out above, at least 2 genera, Helisoma and Oreohelix, and 1 species each of Lymnaea and Physa differentiate the deposits of Utah Lake from the Provo formation.

No artifacts or other evidences of Indian occupancy during Lake Bonneville time have been found, but Indians were present during Utah Lake time. On July 1, 1949, two Indian skeletons in fair degree of preservation were unearthed during excavation of a basement west of Provo, in the NE $1 / 4$ sec. 3, T. 7 S., R. 2 E. The two skeletons were together at a depth of 4 feet, obviously in a grave dug before burial beneath sediments of Utah Lake. One was an adult, the other a small child. No artifacts were found.

Section at the site of Indian grave, west of Provo

Deposited after Indian burial: Inches

Soil, sod, and grass_..................... 4

Soil, $\mathrm{B}$ horizon developed on sand like that below. 10

Sand, medium- to fine-grained, sorted ......... 21

Sand with clay, gray _.................... 12

Top of Indian burial grave (rocks piled over).

Deposited before Indian burial:

Lake tufa, light- to medium-gray, structureless

Sand, fine- to medium-grained, rounded grains;

water-bearing (quicksand). Base not reached_ 28

$84(7 \mathrm{ft})$

\section{ANCIENT SOILS}

Ancient soils have been mentioned previously in the discussion of the deposits on which they are developed, but it seems desirable to discuss them separately in more detail.

At several places in southern Utah Valley are remnants of an ancient thick soil like that described in the northern part of the valley (Hunt and others, 1949, p. 120-122; Hunt and Sokoloff, 1950, p. 109-123; Hunt and others, 1953, p. 43-44). This soil, called the preLake Bonneville soil, commonly is 10 feet or more thick and consists of an upper B horizon of reddish clay or clayey gravel over a lime-enriched Cca horizon that, in turn, grades downward into parent material. This soil 
bears little resemblance to the original parent material.

The pre-Lake Bonneville soil occurs only on deposits older than Lake Bonneville, and is further restricted to those areas that have remained little eroded during Lake Bonneville and subsequent time. It is especially common on the pre-Lake Bonneville fan gravel above the Bonneville shoreline, and has also been found on bedrock in the mountains. In places, especially on fans of pre-Lake Bonneville fan gravel, this soil is overlapped by the Lake Bonneville group, attesting to its pre-Lake Bonneville age. The ancient surfaces on which this soil formed are dissected, and locally, gullies reveal the whole soil profile, and rarely, also a sequence of one or more earlier soils of Quaternary age.

An excellent example of such a sequence is exposed in the Goose Nest-Bear Canyon area southwest of Salem. Bear Canyon is a gully, 36 feet deep in places, excavated in pre-Lake Bonneville fan gravel. The uppermost layer on the ancient fan gravel is 6 to 8 feet thick, dark reddish brown, very clayey, and virtually leached of all lime. It is considered to be the B horizon of the preLake Bonneville soil. The underlying calcareous horizon of this soil is approximately equivalent in thickness, pink to nearly white, with very strong calcium carbonate (caliche) concentration in the upper few feet, grading somewhat weaker downward. The remainder of this exposure consists of several lenticular layers of reddish-brown clayey gravel, several inches to several feet thick, with little or no calcium carbonate concentration, separated by layers of white to pink gravel with strong to very strong calcium carbonate concentration, that are several feet to as much as 8 feet thick. These alternating reddish and whitish layers are thought to be $\mathrm{B}$ and Cea horizons, respectively, of very maturely developed soils that formed during several successive soil-forming intervals, before the last interval of preLake Bonneville soil formation. At this location each soil was buried by deposition of new fan gravel during the times of alluviation that separated the intervals of soil formation.

Another excellent exposure is a road cut in the east wall of Loafer Canyon, in the south-central part of sec. 25 , T. 9 S., R. 2 E., at an altitude of 6,500 feet. Here the pre-Lake Bonneville soil is developed on preLake Bonneville fan gravel consisting of fragments of limestone, orthoquartzite, and sandstone. The upper 6 feet of the soil is reddish-brown and leached of lime; the upper part of this zone is rich in clay and contains many partly decomposed pebbles and small cobbles. Below this zone is a 21-foot zone of strong to very strong calcium carbonate concentration that probably includes the Cca horizon of the yougest pre-Lake Bonneville soil superimposed on those of older Quaternary soils. Presumably alluviation was not sufficiently ac- tive at this locality to bury the soils that formed during successive soil-forming intervals, contrary to the situation at Bear Canyon.

Soils on the Lake Bonneville group and younger deposits are much less well developed than the preLake Bonneville soil. The buried submature soil that formed during the recession between the Alpine and Bonneville lake cycles is discussed on page 111. A maturely developed soil, intermediate in development between the pre-Lake Bonneville and post-Provo, preUtah Lake soil, occurs on the Alpine and Bonneville formations above the Provo shoreline, but not on the upper surfaces of landforms below the Provo terrace; hence, this soil seems to be older than the Bonneville formation and of either pre-Provo or Provo age It is called the middle-Lake Bonneville soil. It generally is 3 to 4 feet thick and has an upper leached horizon and a lower horizon of strong lime enrichment. The submature buried soil of late Provo recession age is discussed on page 119. The upper surfaces of landforms below the Provo terrace bear a mature to submature zonal soil as much as 2 feet thick, with a black, gray, to brown leached horizon over a horizon of moderate lime concentration. The oldest deposits of Utah Lake age bear an immature soil profile 1 or 2 feet thick, but the most recent deposits have no discernible soil profile.

\section{LAKE HISTORY}

The lake history recorded by the late Quaternary deposits in southern Utah Valley can be summarized as follows.

1. A pre-Lake Bonneville period of low or temporary lakes, recorded by the pre-Lake Bonneville fan gravel and pre-Lake Bonneville soil.

2. The first deep-lake cycle of Lake Bonneville, recorded by the Alpine formation, which rose to a maximum at about 5,100 feet altitude. Deposition of mainly lake silt and clay, locally gravel and sand.

3. Lake recession, to at least as low as 4,850 feet altitude, demonstrated by a local disconformity, eolian sand, alluvium and a submature soil between the Alpine and Bonneville formations.

4. Lake rise to the Bonneville shoreline (the highest shoreline of Lake Bonneville, at about $5,135 \mathrm{ft}$ altitude), then regression as low as the Provo shoreline (altitude about $4,800 \mathrm{ft}$ ) recorded by the Bonneville formation. Deposition of mainly lake gravel, some sand, and minor amounts of silt and clay.

5. A major stillstand at the Provo shoreline, recorded by the main part of the Provo formation, followed by regression to at least as low as 4,720 feet, recorded by a local disconformity, eolian sand and silt, and a submature soil. Then a lake rise to 4,760 feet followed by 
a final lake recession to below 4,500 feet, recorded by the uppermost part of the Provo formation, ending Lake Bonneville history in Utah Valley.

6. Lake rise to an altitude of about 4,565 feet, followed by recession to modern levels of Utah Lake, recorded by deposits of Utah Lake.

\section{STRUCTURAL GEOLOGY}

Utah Valley is a structural valley bounded by faults, but folding has contributed to the displacement. Deformation has occurred repeatedly, twice in the Precambrian, again midway in the Cretaceous, and in Late Cretaceous, early Tertiary, late Tertiary, and Quaternary time. As stated by Hunt (Hunt and others, 1953 , p. 39 ):

the folding and thrust faulting of the Paleozoic and Mesozoic rocks in the mountains adjoining Utah Valley occurred during late Mesozoic and earliest Cenozoic time, as it did farther south in central Utah ***. The block faulting by which the valley assumed the shape and proportions we see today occurred later and was superimposed on the older structures.

Nolan (1943, p. 182-184) has pointed out that structural and physiographic evidence shows that block faulting occurred at different times in different places, and it started early in the Tertiary period, probably in late Eocene or early Oligocene time, was widespread through the later Miocene and early Pliocene, and is still continuing. In Tertiary time Utah Valley became defined, along its eastern boundary at least, mainly by normal faulting.

Along the front of the Wasatch Mountains the Paleozoic rocks in general are displaced by both normal and reverse faults, trending either parallel or very slightly oblique to the mountain front, forming a fault zone that is known as the Wasatch fault zone. Hunt (Hunt and others, 1953, p. 38-39; pl. 1) mapped a series of en echelon to bifurcating faults along the west base of the Wasatch Range in northern Utah Valley, and the southward continuation of this fault zone in southern Utah Valley has similar characteristics; for example, northeast and east of Springville. Older faults, such as the Maple Flat fault which crosses Slate Canyon, intersect the frontal fault zone at acute angles and are displaced by the Wasatch fault zone.

The scarp of the Wasatch fault zone is well defined northeast of Springville. The mountains here jut farther westward into Utah Valley than contiguous parts of the range, and the spurs are strikingly faceted: Generally the faults in this fault zone dip westward, and hence are normal. At a few localities, however, particularly east of Provo, Mapleton, and Spanish Fork, small young scarps show that their faults dip to the east, indicating that reverse faulting has occurred locally. If so, it may have been accomplished by normal upthrusting in which the footwall block was active, as interpreted by Hunt (Hunt and others, 1953, p. 39): "the mountains were raised, the valley lagging behind. Perhaps the valley was raised also, though less so than the mountains. Probably during the earlier movements too the valley block has been more passive than the mountains." Similar examples occur along the west base of Maple Mountain, the north base of Loafer Mountain, southwest of Salem, and the west base of Dry Mountain east of Santaquin.

Some of the faults in the Wasatch fault zone displace alluvial fans, some displace only the oldest fans, and some are younger than the post-Provo, pre-Utah Lake fans. On the west face of the mountain between Maple and Spanish Fork Canyons are three sets of triangular facets, each having different inclination toward the valley, indicating intermittent faulting. This particular mountain has been made classic by Davis (1903, p. 152-155; fig. 11, pl. 1), who pointed out the nature of the faceted spurs on its west flank.

Such evidence indicates that the many thousands of feet of displacement represented by the Wasatch fault zone was produced by repeated small movements over a very long time (Hunt and others, 1953, p. 38). Several thousand feet of displacement have occurred since the Salt Lake formation was deposited. The pre-Lake Bonneville fan gravel has been displaced at least 150 feet, and the Lake Bonneville group as much as 50 feet.

Surficial evidence of faulting along the east side of Long Ridge is lacking, but a fault or faults could be concealed under the valley-fill deposits. On the other hand, both structural and physiographic evidence suggest a normal fault along the west base of Long Ridge west of Santaquin and along the north base south of Goshen and Elberta. Eaton (1929, p. 71-79) indicated normal faults of considerable throw on both sides of West Mountain, but evidence to substantiate such an interpretation seems to be lacking. Eardley (1934) shows a fault along the west base of Long Ridge continuing northward beneath alluvium toward the west base of West Mountain. Andrews and Hunt (1948) show this fault extending north along the west side of Long Ridge east of Goshen, then veering almost due east past Santaquin and joining with the Wasatch fault near Payson. Both interpretations seem inadequate; rather, it seems that the Goshen Valley fault rapidly dies out to the north and likely is a minor feature between Payson and West Mountain.

According to Gilbert (1890, p. 365-373), the deposits of Lake Bonneville have been slightly warped, and Utah Valley has been tilted slightly southeastward. Although no detailed studies have been made of post-Lake 
Bonneville deformation in Utah Valley, Hunt and others (1953, p. 39) pointed out:

Well data $* * *$ indicate that the formations comprising the valley fill in Utah Valley thicken southeastward and probably the bedrock surface is deeper at the south than at the north. These data, combined with those gathered by Gilbert, suggest that the southeastward tilting of Utah Valley, like the faulting, has progressed intermittently since the valley was formed.

Except for the broad interbasin warping there is little evidence of structural movements in the sediments in the valley. The Provo formation and deposits of Utah Lake locally are broken by small normal and reverse faults, but these breaks may reflect settling or compaction of basin-fill sediments rather than deepseated structural movements.

\section{ENGINEERING GEOLOGY GRAVEL}

In this report all unconsolidated clastic sediments that are coarser textured than sand are mapped as gravel. These deposits are not necessarily commercially workable gravel, and they may contain appreciable amounts of sand, silt, and clay. The same is true for other facies distinctions; the geologic map is thus only a general guide to areas of earth materials. Finding commercial gravel deposits requires further investigation, including sampling by excavation, or boring to determine thickness, lateral extent, composition, and lateral and vertical changes in material.

Most of the better gravel deposits in southern Utah Valley are beach, spit, bar, and delta deposits of Lake Bonneville, and generally lie near the mountains. A few deposits of Utah Lake have been worked on a small scale. The fan gravel generally is of low grade, for it contains much admixed clay, silt, and sand; the gravel is angular to subangular; and the beds are thin and discontinuous. The deposits commonly have fair stability and make good coarse base material for highways; for example, several such deposits were used in the construction of a new addition to U.S. Highway 89 and 91 east of Santaquin.

One of the major producing deposits is the combined delta and alluvial fan at the mouth of Slate Canyon. It has been exploited for more than 20 years for gravel and sand, and today provides much material for readymixed concrete. The lower part of the deposit is deltaic gravel and sand of the Provo formation, which is clean and well sorted; the upper half of the deposit is fan gravel and is very poorly sorted and must be washed to free it of admixed fine-textured material. Caliche cement in the upper 5 to 10 feet of the gravel hampers excavation and disaggregating; most of this material must be discarded because the caliche renders the gravel unsatisfactory for concrete aggregate.
Gravel of the Alpine and Bonneville formations south of the mouth of Slate Canyon along the Wasatch Mountain front is being worked on a small scale, but these deposits are only thin blankets on the mountain slope and contain as much as 50 percent of fines.

A few gravel pits have been opened in the large Springville-Spanish Fork delta. Three practically adjoining pits at the northeast edge of Springville in the NW 14 SE $1 / 4$ sec. 34 , T. 7 S., R. 3 E., and one pit in the SW $1 / 4$ sec. 34 , T. 7 S., R. 3 E. expose rather thin and discontinuous gravel beds, containing as much as 60 percent admixed sand, silt, and thin clay lenses; the upper 5 feet or more is impregnated with lime. In this same delta southeast of Spanish Fork a few pits have been dug adjacent to the Spanish Fork River valley; however, excessive amounts of admixed fine necessitates screening and washing. Near the distal end of this delta southwest of the city are a few workable gravel beds, but even these are thin, discontinuous, and only locally well sorted.

South and southwest of Salem and south and southeast of Payson gravel bars and a large spit in the Lake Bonneville group and post-Provo alluvial fans contain large quantities of gravel suitable for construction. The bars are mostly heterogeneous mixtures of rocks of varied composition; but the spit contains a large proportion of volcanic pebbles, cobbles, and boulders, some of which are very hard, but others are somewhat "rotten."

South of Payson, near Spring Lake, and in the vicinity of Santaquin are some workable gravel deposits. Several are well suited for economic developmentsubrounded to round pebble to cobble gravel, composed of rocks having moderate to high shearing strength. The upper few feet commonly are lime impregnated and require blasting or other expensive methods of loosening. The lime-cemented gravel must be either discarded or allowed to weather for about 1 year to effect disaggregation.

The gravel deposits flanking West Mountain have been opened only by four small pits which, other than for occasional use by farmers, are inoperative. Two of the pits are in pre-Lake Bonneville fan gravel, which requires much excavating and sorting. The other pits are in deposits of Utah Lake and much of the gravel is disc-shaped beach shingle. Two large spits, one on the north, the other on the northwest side of the mountain, likely contain the most gravel and also some of the best sorted; much of the gravel is quartzitic, and hence of high strength.

Some gravel occurs northwest of Elberta, but it is thin, poorly sorted, and less accessible than many better deposits. This gravel, however, has been utilized for local building purposes and for roadbed gravel 
for the Tintic Branch of the Denver \& Rio Grande Western Railroad.

Very few of the gravel deposits surrounding Lake Mountain have been utilized, principally because of the distance to markets. Most deposits are near graveled roads and are fairly extensive, but they occur in rather thin blankets and are commonly lime impregnated in the upper few feet.

The water table commonly is low in the deltas and spits, enabling deep excavations to be made without encountering water. Where uncemented, the gravel slides readily; but where cemented, it commonly stands well in vertical walls without support, even in deep cuts, such as the railroad cuts across the SpringvilleSpanish Fork delta.

All the gravel deposits are permeable, particularly those of Lake Bonneville, and canals and ditches crossing them commonly require lining with clay or concrete. The high canal of the Strawberry Water Users Association is lined with concrete around the Payson spit.

\section{SAND}

To date (1962) few sand pits have been opened, but there are many potentially commercial deposits on otherwise unproductive land. Most of the sand deposits are in deltas and in bars in front of deltas; some are in littoral-zone blankets or beaeh deposits. Very few are in the alluvial fans, and they are admixed with gravel. The sand is commonly subangular to angular except the coarser fractions, which commonly are subrounded. Some deposits have appreciable silt, and clay is locally present.

The deltas of Provo age have the largest sand deposits. In the Springville-Spanish Fork delta the sand deposit is 10 feet or more thick in places, but commonly thinner. It is mostly medium- to finegrained sand, containing beds of coarse sand and grit locally. The quality of the sand varies with its source. Quartzitic sand is most desirable for construction and also for foundry sand. Sand from volcanic materials tends to be of low strength. Most of the deposits are easily worked, as they have a deep water table and generally little or no overburden.

South, southeast, and southwest of Goshen is a very large deposit in a delta and beach littoral-zone blanket, only 2 miles from the main highway and railroad. It ranges in thickness commonly from 5 to 10 feet to tens of feet. Much of the sand is medium and fine grained, however, and thus is too fine for many uses, although it is quartzitic. Admixed silt is locally present, which would require screening or washing; little clay is present. The sand has very good stability when moist, it is relatively clean and well sorted and predominantly subangular. No overburden is present other than a thin veneer of soil and eolian sand and silt.

\section{CLAY}

The lake deposits of clay, widely exposed on the valley bottom, generally are waterlogged and provide poor foundations for roads, buildings, and other construction; they commonly are difficult to work. Drainage canals and ditches must be excavated when the clay is wet, otherwise a blocky and very hard sediment results. Canals, ditches, and other water-control structures show little or no seepage loss. Some deposits near Provo are worked on a small scale for brick clay used in making adobe bricks, lining blast furnaces at Geneva and Ironton, and in the foundry south of Provo.

Some recently constructed buildings near Provo have had engineering failures because they were constructed upon clay without making adequate provision for subsidence. The steel plant at Ironton between Provo and Springville is situated in a graben of a fault zone west of the frontal Wasatch fault zone, and ground water has caused much difficulty. Excavations during 1942-43 for an addition to the plant revealed a fault with gravel on the east (downthrown) side, and clay on the west (upthrown) side. Foundations for the new furnaces and blowing-engine house were laid on this fault. Geologists recommended a well-point system and drainage facilities for the gravel, but the recommendation was not adopted until ground water rose through the gravel bed into the furnace and blowing-engine house.

\section{OTHER MATERIALS}

Calcareous tufa and travertine have been utilized locally in buildings. Small deposits occur along the south end of Lake Mountains, the west side of the Cedar Valley Hills just west of Lake Mountains, in the low hills south of Lake Mountains (the Fox Hills), and along the north end of West Mountain at the lakeshore.

The diatomaceous marl and diatomite near Elberta, in the silt member of the Provo formation, have scarcely been utilized commercially, but they may have value for insulation and perhaps as a filtering medium.

\section{REFERENCES CITED}

Andrews, D. A., and Hunt, C. B., 1948, Geologic map of eastern and southern Utah: U.S. Geol. Survey Oil and Gas Inv. Prelim. Map 70.

Atwood, W. W., 1909, Glaciation of the Uinta and Wasatch Mountains: U.S. Geol. Survey Prof. Paper 61, 91 p.

Auerbach, H. S., 1943, Father Escalante's Journal, 1776-1777: Utah Hist. Quart., v. 11, p. 64-66.

Baker, A. A., 1947, Stratigraphy of the Wasatch Mountains in the vicinity of Provo, Utah: U.S. Geol. Survey Oil and Gas Inv. Prelim. Chart 30. 
Bissell, H. J., 1942, Preliminary study of the bottom sediments of Utah Lake, in Trask, P. D., chm., Report of the committee on sedimentation: Natl. Research Council, Div. Geology and Geography Ann. Rept. 1940-41, p. 62-69.

Butler, B. S., Loughlin, G. F., Heikes, V. C., and others, 1920, The ore deposits of Utah: U.S. Geol. Survey Prof. Paper $111,672 \mathrm{p}$.

Cameron, F. K., 1905, The water of Utah Lake: Am. Chem. Soc. Jour., v. 27, p. 113-116.

Clarke, F. W., 1884, A report of work done in the Washington laboratory during the fiscal year 1883-84: U.S. Geol. Survey Bull. 9, 40 p.

Davis, W. M., 1903, Mountain ranges of the Great Basin: Harvard Mus. Comp. Zoology Bull. 42, p. 129-177.

Decker, L. B., and Maw, C. E., 1933, Chemical analysis of Utah Lake water: Utah Acad. Sci. Proc., v. 10, p. 35-40.

Dixon, B. E., 1934, The determination of carbon in rocks and minerals: Analyst [London], v. 59, p. 739-743.

Eardley, A. J., 1934, Structure and physiography of the southern Wasatch Mountains, Utah: Michigan Acad. Sci. Papers v. 19 , p. $377-400$.

Eaton, H. N., 1929, Structural features of Long Ridge and West Mountains, Utah: Am. Jour. Sci., 5th ser., v. 18, p. 71-79.

Fenneman, N. M., 1928, Physical divisions of the United States: Assoc. Am. Geographers Annals, v. 18, p. 333346 and accompanying map.

Gilbert, G. K., 1875, Lake Bonneville, in Report upon the geographic and geologic exploration and survey west of the 100th meridian: Washington, U.S. Govt. Printing Office, v., 3.

1890, Lake Bonneville: U.S. Geol. Survey Mon. 1, $438 \mathrm{p}$.
Hoff, C. C., 1942, The ostracods of Illinois: Urbana, Ill., Univ. Illinois Press, Illinois Biol. Mon. 19, $196 \mathrm{p}$.

Hunt, C. B., Creamer, A. S., and Fahey, J. J., 1949, A newly discovered type of clay deposit in Utah: Washington Acad. Sci. Jour., v. 39, no. 4, p. 120-122.

Hunt, C. B., and Sokoloff, V. P., 1950, Pre-Wisconsin soil in the Rocky Mountain region: U.S. Geol. Survey Prof. Paper 221-G, p. 109-123.

Hunt, C. B., Varnes, H. D., and Thomas, H. E., 1953, Lake Bonneville: Geology of northern Utah Valley, Utah:U.S. Geol. Survey Prof. Paper 257-A, p. 1-99.

King, Clarence, 1878, Systematic geology: U.S. Geol. Survey Explor. 40th Parallel, v. 1, 803 p.

Lane, E. W., and others, 1947, Report of the subcommittee on sediment terminology: Am. Geophys. Union Trans., v. 28, no. 6, p. 936-938.

Lee, W. T., 1924, Geography, geology, and physiography of the Great Salt Lake basin: in U.S. Geol. Survey WaterSupply Paper 517, p. 3-9.

Lindgren, Waldemar, and Loughlin, G. F., 1919, Geology and ore deposits of the Tintic mining district, Utah: U.S. Geol. Survey Prof. Paper 107, 282 p.

Loughlin, G. F., 1918, Two lamprophyre dikes near Santaquin and Mount Nebo, Utah: U.S. Geol. Survey Prof. Paper 120-E, p. 101-109.

Nolan, T. B., 1943, The Basin and Range province in Utah, Nevada, and California: U.S. Geol. Survey Prof. Paper 197-D, p. 141-196.

Richardson, G. B., 1906, Underground water in the valleys of Utah Lake and Jordan River, Utah: U.S. Geol. Survey Water-Supply Paper 157, 81 p. 


\section{INDEX}

A

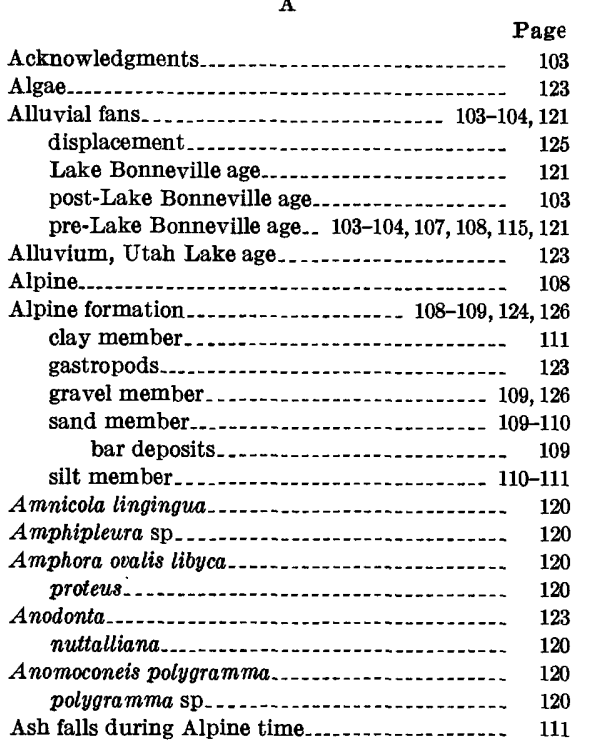

B

Bar deposits, sand member of Alpine formation.. Bar graphs of mechanical analyses, gravel from the Bonneville formation.. gravel member of Provo formation......... 115

Bars............................. 104, 109, 113, 126, 127 gravel of Bonneville formation.............. 113 of Provo age Bartholomew Canyon........................... 107

Beach deposits, Provo age................... 113, 114 Utah Lake. . . ................................ 122 Bear Canyon.

Benjamin

Bonneville formation.................... 111-12, 124, 126

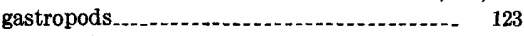
Bonneville shoreline........... 108, 111, 112, 113, 121, 124

Brigham Young University campus, road-cut exposures.

Buckley Mountain

Building materials.............................. $\quad 127$

\section{C}

Caloneis a mphisbaena.

120

schumanniana-

silicula. . .

Candona candida

lactea

Carivifex newberryi

Chemical analyses, water from thermal springs in or near Utah Lake...............

water in Utah Lake. ...........................

water of surface streams emptying into Lake Utah. . .

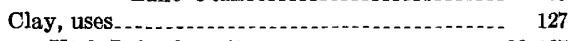

Utah Lake deposits . . . . . . . . . . . . . . 122, 127

Cocconeis disculus.................................. 120

grovei...

placentula.

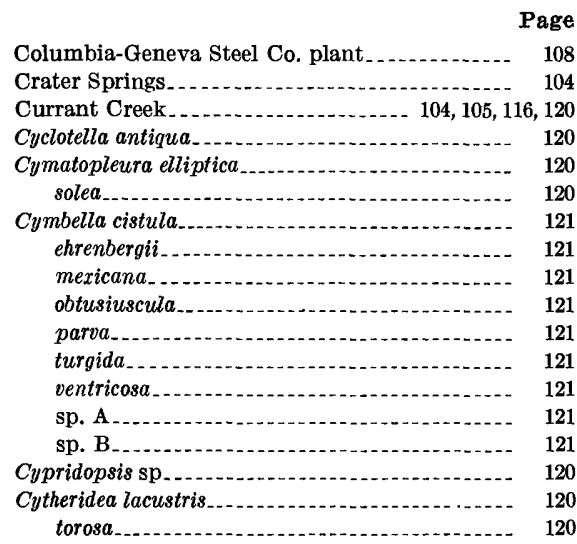

\section{$\mathrm{D}$}

Deltas..................... 103, 104, 113, 114, 126, 127 Goshen .......... 116 of Provo age............. 113, 114, 115, 117, 121, 127 Spanish Fork...................... 116, 117, 119

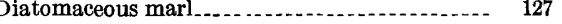
silt.

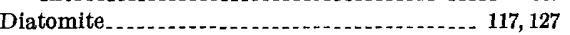
Diatoms, silt member of Provo formation. 117, 120-121

Dike, lamprophyre........................ 107

Diploneis ovalis................................ 121 smithlii....

Disconformity, between Alpine and Bonneville formations .............. 111,112,113

between uppermost part of Provo formation and main part.................... 119

Dry Mountain.

Dunes....... 121

\section{E}

East Tintic Mountains _. 101, 103, 107, 110, 111, 112, 116 Elberta . . . . ..... 106, 109, 110, 116, 117, 119, 121, 124, 127 Elephant, Pleistocene............. 117, 119 Elephas sp.................................... 117

Embankment deposits, Alpine formation . . . . . 110 gravel of Provo formation sand member of Provo formation.......... 116

Embankments above Provo shoreline . ......... 110

Eolian sand and silt, post-Provo................ 121

Epithemia arbus............................. 121 sorex

turgida

zebra. porcellus saxonica ......... 121 sp_._. Eureka_......... 106

Fan gravel, Lake Bonneville age late and post-Provo, pre-Utah Lake..... 121-122 pre-Lake Bonneville_- 107, 115, 117, 121, 124, 125, 126 Utah Lake age. . . . . . Fault scarp east of Mapleton.

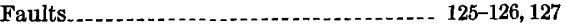

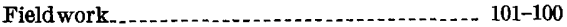
Fluminicola fusca $\ldots \ldots \ldots \ldots \ldots \ldots \ldots$ Fort Utah.

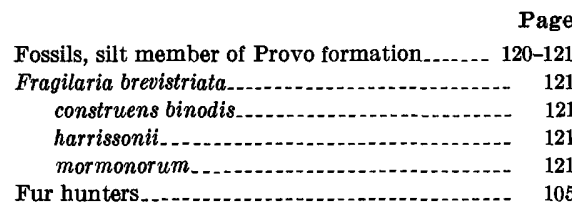

G

Gazin, C. L., fossil identification by .........- 109 Genola Church._._. 117 Geology ................. 106; pl. 5 Glass shards.................................. 111 Goose Nest.-.............. 107 Goose Nest-Bear Canyon area, soils of Quaternary age Goshen....... 103, 104, 105, 106, 109, 116, 117, 121, 125, 127 Goshen Bay of Utah Lake................ 119, 122 Goshen Valley.......................... 103,115,117 Goshen Valley fault. ......................... 125 Gravel, suitable for construction.............. 126 Gravel pits............... 109, 114, 115, 117, 119-120, 126

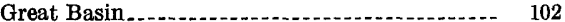
Great Salt Lake $\ldots . . . \ldots$ Green River formation, shale............... 119 Gyrosigma parkeri.

H

Hantzschia amphioxys uticensis._._......-...-- 121 Helisoma...................- 123 trivolvis binneyi. . . . Hobble Creek. ......................... 103, 104, 114, 121 Hobble Creek-Spanish Fork delta.......... 114, 117 Hoff, C. C., quoted............................. 120 Hunt, C. B., quoted......... 111, 113, 122, 125, 126

I

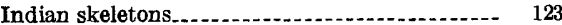
Ironton $\mathrm{J}$

Jordan River. Juab Valley............ 101, 103, 113, 116, 120

$\mathbf{K}$

Kutzingiana planetophora

$\mathbf{L}$

Lake Bonneville, clay _.............. 122 ending of gravel deposits............................. 127 high-water level. post-Provo stillstand ...................... 122 previous studies ........ 102-103 Quaternary deposits......................... 106 recession ........................ 111, 113, 124-125 size Lake Bonneville basin, mapping program . ...- 102 Lake Bonneville group........ 107-121, 123, 124, 125, 126 Lake history . . . . . . . . Lake Mountains...... 101, 103, 104, 106, 107, 112, 122, 127 Lake plain . . . . . . . . Lake Shore............. 106

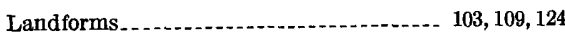
Lehi 


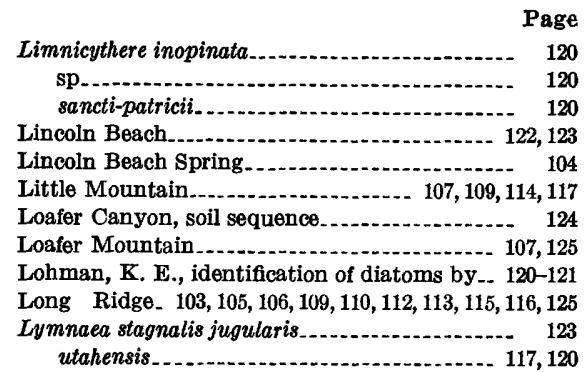

$\mathbf{M}$

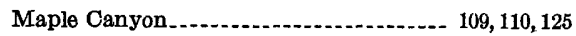
Maple Creek....................... 103,104

Maple Creek Canyon.......................... 108 Maple Flat fault. Maple Mountain

Mapleton ................ 106, 108, 109, 110, 117, 118, 125

Mapleton Bench.............................. 121

Mapping of area_........... 101, 102

Mastogloia elliptica

smithii lacustris........................

Mechanical analyses, gravel member of Alpine formation.

ravel member of Provo formation.

sand member of Provo formation............ 117

silt member of alpine formation............... 111

silt member of Provo formation

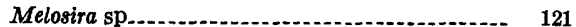

Mesozoic era, rocks.

Mollusks, gravel member of Provo formation... 114

Lake Bonneville group

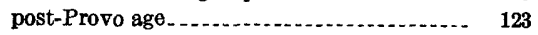

Provo formation ............................. 123

silt member . ......................... 117, 120

Utah Lake deposits........................ 123

Moraines....... 107

Mormon pioneers.

Mosida $\ldots \ldots \ldots \ldots . . . .117,122$

Mosida Hills .................................. 107

Musk ox skull in sand lens of gravel of Alpine formation.......................... 100

\section{$\mathrm{N}$}

Navicula anglica.

oblonga .................................... 121

popula capitata

radiosa.

reinhardtii .

tuscula.

viridula

sp. A

sp. $\mathrm{C}$

sp. D.

dium distincte-punctatum

$\mathrm{sp}$..

Nitzschia signoidea

121

North Fork $\ldots 7$

O

Oquirrh formation $\ldots . . . \ldots \ldots \ldots \ldots \ldots \ldots \ldots . . . \ldots 116,122$ Oreohelix strigosa depressa....................... 123 Ostracodes from silt member of Provo formation. $\quad 120$

\section{$\mathbf{P}$}

Paleozoic rocks 106 Palmyra Payson........103, 104, 106, 107, 109, 117, 119, 121, 125, 126

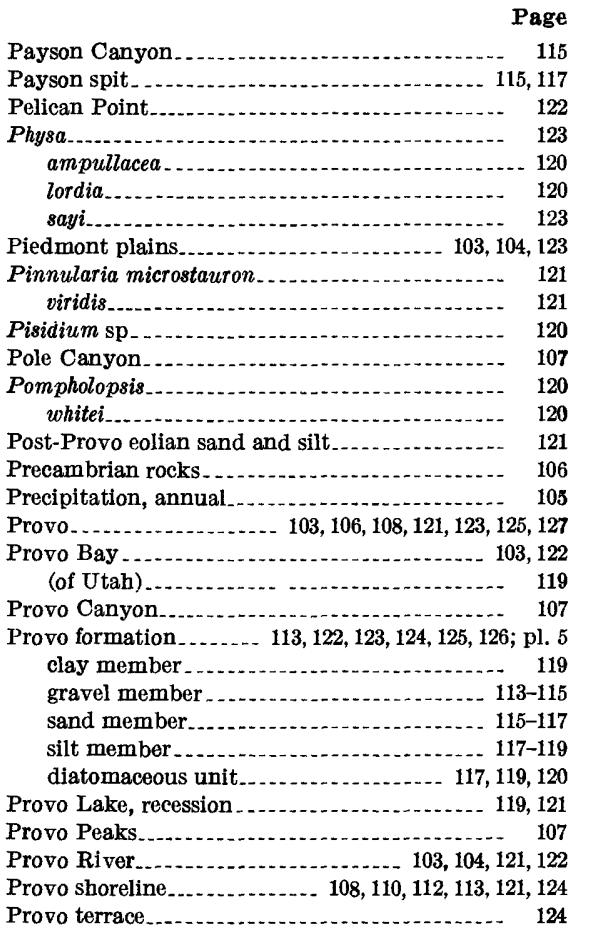

\section{Q}

Quaternary lakes of the Great Basin, mapping. 102-103

\section{R}

Rhoicosphenia curvata. 121 Rock Island.... 121

\section{S}

Salem........ 104, 106, 109, 110, 111, 112, 115, 116, 117, 121, $124,125,126$ Salt Lake basin................................ 122 Salt Lake formation, outcrops ............. 106-107

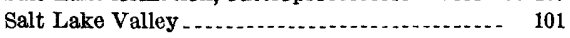
Sand pits................................. 127 Santaquin _...103, 104, 106, 108, 109, 110, 111, 112, 113, 115, $\begin{array}{rrr} & 116,117,121,125 \\ \text { Santaquin Canyon } \ldots \ldots & 107\end{array}$ Saratoga Saratoga Springs.

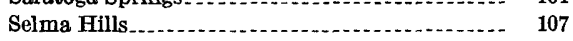
Slate Canyon $\ldots \ldots \ldots \ldots$.............. 110, 112, 114, 125, 126 Solls, ancient. ........................... 107, 123, 124 Calcic Brown middle-Lake Bonneville................. 121, 124 pre-Lake Bonneville................... 111, 123-124 submature, on Lake Bonneville....... 113, 114, 124 post-Provo, pre-Utah Lake ............ 114, 121 Provo formation . South Fork Spanish explorers............................ 105 Spanish Fork Spanish Fork (rity) ...... 106, 115, 116, 117, 119, 121, 125 Spanish Fork Canyon............ 105, 106, 108, 110, 125 Spanish Fork Peak ........................ 107 Spanish Fork River . . . Sphaerium pilsbryanum
Page

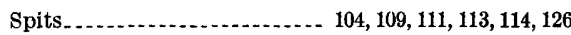
gravel member of Alpine formation........ 109 gravel of Utah Lake deposits . .............. 122 Lake Bonneville group...................... 126 of Provo age ...................... 113, 114-115, 117 Spring Creek ............... 114 Spring Lake Springs, thermal. Springville_...................... 103, 106, 107, 110,112, $114,115,119,121,125,127$ Springville-Spanish Fork delta ........... 126, 127 Stansbury shoreline............................ 122

Stavroneis perpusilla.......................... 121

Stratigraphic sections, Alpine formation........ 108 Provo formation.......... 117

Salt Lake formation................. 107 site of Indian grave, west of Provo........... 123

Strawberry Water Users Association........... 127

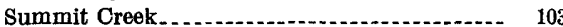

Surirella crumena linearis..................................... 121

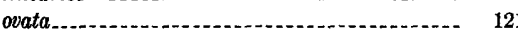

testudo

utahensis................................... 121

sp.

Symbos.

Synedra pulchella

Swain, F. M., ostracodes identified by............

$\mathbf{T}$

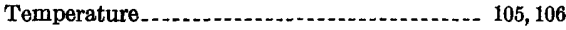

Terrace deposits, shore

Terraces, Provo.................................. 124

shore

Tertiary age, nonmarine sedimentary rocks and lava flows......................... 106

Tintic Branch of the Denver \& Rio Grande Western Railroad.................... 127

Tintic formation....... 116

Towns.......

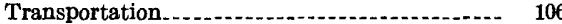

Traverse Range.

Travertine. . .

Tufa, calcareous............ 127

Tufa unit, Utah Lake deposits.............. 122-123

$\mathrm{U}$

Utah Lake. . ...................... 103, 104, 105, 117, 125

Utah Lake deposits......................... 122-123, 126

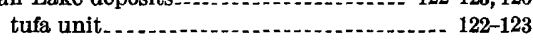

Utah Lake of Recent(?) age . . . . . . . . . .

Utah Valley .................... 101, 103, 105, 107, 113, 125

V

Valvata utahensis 117,120

Volcanic rocks 115

\section{W}

Warm Creek

Wasatch fault zone. 105 Wasatch Mountains.............. 101, 103, 104, 105, 106, $107,108,109,110,111,112,113,125$

Wasatch Range.......... 125 Water, salinity .

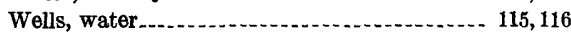

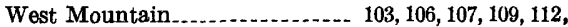

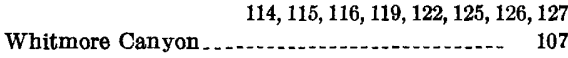

Y

Yen, Ten-Chien, identification of mollusks by Young, Brigham.

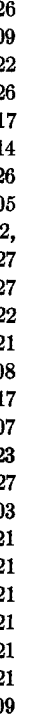

